\title{
The Super Efficient Refrigerator Program: Case Study of a Golden Carrot Program
}

Jan B. Eckert

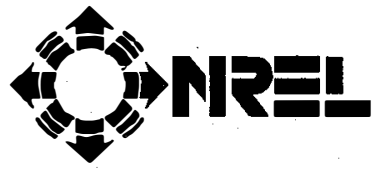

National Renewable Energy Laboratory 1617 Cole Boulevard Golden, Colorado 80401-3393

A national laboratory of the U.S. Department of Energy Managed by Midwest Research Institute under contract No. DE-AC36-83CH10093

Prepared under Task No. AS135441

July 1995 


\section{NOTICE}

This report was prepared as an account of work sponsored by an agency of the United States government. Neither the United States government nor any agency thereof, nor any of their employees, makes any warranty, express or implied, or assumes any legal liability or responsibility for the accuracy, completeness, or usefulness of any information, apparatus, product, or process disclosed, or represents that its use would not infringe privately owned rights. Reference herein to any specific commercial product, process, or service by trade name, trademark, manufacturer, or othenwise does not necessarily constitute or imply its endorsement, recommendation, or favoring by the United States government or any agency thereof. The views and opinions of authors expressed herein do not necessarily state or reflect those of the United States government or any agency thereof.

Available to DOE and DOE contractors from:

Office of Scientific and Technical Information (OSTI)

P.O. Box 62

Oak Ridge, TN 37831

Prices available by calling (615) 576-8401

Available to the public from:

National Technical Information Service (NTIS)

U.S. Department of Commerce

5285 Port Royal Road

Springfield, VA 22161

(703) $487-4650$ 


\section{Preface}

The work in this report was conducted by the Analytic Studies Division (ASD) of the National Renewable Energy Laboratory (NREL) for the U.S. Department of Energy Office of Energy Efficiency and Renewable Energy, Office of Building Technologies. This case study describes the development and implementation of the Super Efficient Refrigerator Program (SERP), which awarded $\$ 30$ million to the refrigerator manufacturer that developed and commercialized a refrigerator that exceeded 1993 federal efficiency standards by at least $25 \%$. The program was funded by 24 public and private utilities. As the first Golden Carrot program to be implemented in the United States, SERP was studied as an example for future "market-pull" efforts.

Many ASD staff members reviewed drafts of this document, including Barbara Farhar, project leader, Jeffrey Fang, Larry Goldstein, Mark Bernstein, Bill Babiuch, Karen Thomas, Katherine Mayo, Ron White, and Tom Wheat. Other NREL staff members who contributed to the publication of this document include Nancy Greer, Mary Donahue, Mary Anne Dunlap, and Kay Vernon. Michael L'Ecuyer of the Global Change Division at the U.S. Environmental Protection Agency, Ray Farhang with SERP ${ }^{\mathrm{TM}}$, Inc. and

Rebecca Vories of Infinite Energy, Inc., provided information on the program and reviewed and commented on drafts of this report.

Approved for the

NATIONAL RENEWABLE ENERGY LABORATORY

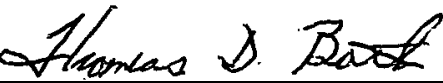

Thomas D. Bath, Director

Analytic Studies Program

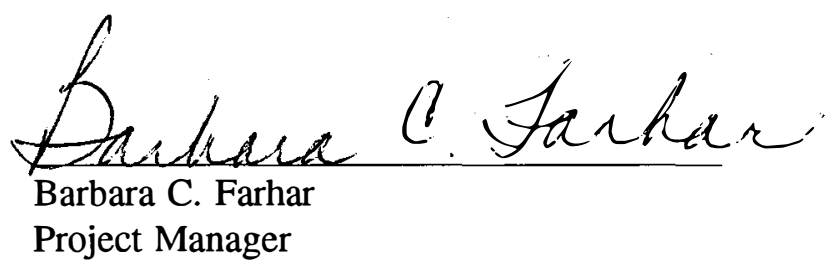




\section{Executive Summary}

This report is a case study of the Super Efficient Refrigerator Program (SERP), the first Golden Carrot program to be implemented in the United States. The term "Golden Carrot" is used in this text to describe programs that aim to accelerate the development and commercialization of super-efficient end-use technologies through incentives to product manufacturers. The purpose of this case study is to examine the development and implementation of the SERP model, describe the regulatory and research and development (R\&D) contexts in which the super-efficient refrigerator was conceived, explain the development and implementation of the SERP bid process, outline several other Golden Carrot initiatives, and raise a number of policy questions. Programs such as SERP are receiving attention from policy makers and utilities as possible cost-effective options for increasing the use of energy efficiency technologies by utility customers. These programs aim to speed development and foster market penetration of super-efficient end-use technologies through incentives to product manufacturers. Such programs seek long-term efficiency gains and changes in production and purchasing priorities. In so doing, these programs could significantly increase the energy efficiency of specific industrial, commercial, and residential end-use technologies, stimulate private-sector investment, and decrease greenhouse gas emissions.

The U.S. Department of Energy's (DOE's) R\&D results and several studies established that it was possible to combine existing and emerging technologies to produce super-efficient, chlorofluorocarbon- (CFC)-free refrigerators. In addition, the promulgation of more stringent National Appliance Energy Conservation Act (NAECA) standards for R/Fs in 1993 (P.L. 94-163; P.L. 100-12) and a 1992 federal mandate requiring manufacturers to eliminate the use of CFCs in R/Fs in 1996 (Clean Air Act Amendments of 1990, Title VI) made refrigerator technology an appropriate candidate for a Golden Carrot program.

The SERP Program featured a $\$ 30$ million bid competitively awarded to the refrigerator manufacturer that could develop, distribute, promote, and sell the most energy-efficient, CFC-free refrigerator/freezer (R/F) in the most cost-effective manner possible. The program took shape in 1990 when representatives from the Pacific Gas and Electric Company (PG\&E), the Washington State Energy Office (WSEO), the Natural Resources Defense Council (NRDC), the American Council for an Energy Efficient Economy (ACEEE), and the U.S. Environmental Protection Agency (EPA) met to discuss strategies for encouraging manufacturers to develop and commercialize more energy-efficient R/Fs.

Meeting participants drafted a program outline that they presented as part of the January 1991 National Utility Workshop on Very Efficient Refrigerator Programs sponsored by PG\&E and WSEO. The workshop provided a forum for examining existing programs promoting refrigerator efficiency and for planning a Golden Carrot program for R/Fs. Interested workshop participants continued to meet throughout the year and, in September 1991, formed two organizations, the Super Efficient Refrigerator Program, Inc. (SERP ${ }^{T M}$, Inc.), and the Consortium for Energy Efficiency, Inc. (CEE), to promote Golden Carrot initiatives for refrigerators and other end-use technologies, respectively.

PG\&E, Southern California Edison (SCE), Bonneville Power Administration, Sacramento Municipal Utility District, Los Angeles Department of Water \& Power, Long Island Light Company, NRDC, ACEEE, and EPA formed CEE to promote energy efficiency and pollution prevention through the commercialization of new, super-efficient appliances and other technologies. The organization facilitates Golden Carrot strategies by selecting super-efficient technologies for commercialization and coordinating utility involvement to expedite market penetration of these technologies. SERP was the first CEE-endorsed Golden Carrot initiative. 
With the consent of their Public Utility Commissions, six utilities formed SERPTM, Inc. to be the central fiscal and decision-making body for the Golden Carrot refrigerator program. They were joined by 18 other public and private utilities. SERPTM, Inc. utilities are the organization's sole source of funding. From late 1991 until the summer of 1992, members of SERPTM, Inc. in partnership with environmental groups and EPA, worked out the details of the $\$ 30$ million, winner-take-all competition.

In July 1992, SERPTM, Inc. launched the competition. Participating refrigerator manufacturers had three months to develop proposals for R/F prototypes that had automatic defrost, were CFC-free, had the capacity of conventional units, and were at least 25\% more efficient than 1993 applicable federal standards. In addition, the manufacturers had to show that they were capable of producing, promoting, selling, and distributing the units according to a delivery schedule proposed in the bid, and that they were able to track sales of at least $75 \%$ of the units produced and shipped. An independent team of experts judged the first round of proposals and selected Frigidaire and Whirlpool to compete in a runoff. A second team of evaluators scored the finalists' bids and prototypes, and in June 1993, SERPTM, Inc. announced Whirlpool the winner. Whirlpool will manufacture and deliver approximately 250,000 units to the market in the service territories of participating utilities between 1994 and 1997.

SERPTM, Inc. capitalized on existing competition in the $\mathrm{R} / \mathrm{F}$ industry to attract manufacturer bids. Although Whirlpool had doubts about participating in the competition, the potential to increase the company's market share, should Whirlpool win, proved to be the key incentive. In addition to receiving positive publicity, the competition guaranteed that initially the winner would face no competition from other leading manufacturers. In 1992, Whirlpool was second in the industry, capturing 25 percent of the market; General Electric controlled 35 percent of the market, and Frigidaire 19 percent.

The SERP Program raises a number of policy questions that address the SERPTM, Inc. Program model and its replication. These include: How was the program actually designed and carried out? Would a federal standards program be more effective in increasing appliance efficiency if it were linked with a Golden Carrot incentive program? What problems were encountered and how were they resolved? Is the SERPTM, Inc. model transferable to other technologies? What is the appropriate federal role with respect to Golden Carrot programs?

Results from the SERP Program are promising. Whirlpool is meeting its delivery and sales schedules and competing R/F manufacturers are beginning to market their own super-efficient models. A significant outcome of the SERP process has been the unprecedented agreement reached by the Association of Home Appliance Manufacturers, NRDC, ACEEE, PG\&E, SCE, the California Energy Commission, and the New York State Energy Office to establish and propose to DOE 1998 NAECA standards for R/Fs. DOE's 1998 proposed standards for the SERP class of R/F are similar to those proposed by this group. The proposed regulations appeared in the Federal Register on July 20, 1995.

The long-term impact of the SERPTM, Inc. Program is still being evaluated. Data are needed on such aspects as regional markets, frequency of sales, environmental and dollar savings of the SERPTM units, the percentage of the market captured by super-efficient units, and the changes in super-efficient refrigerator supply as other manufacturers enter the arena. In 1994, CEE began piloting alternative Golden Carrot strategies for end-use technologies such as high-efficiency air conditioners, residential clothes washers, and split-system heat pumps and air conditioners.

The deregulation and restructuring of the electric utility industry will likely affect utility involvement in Golden Carrot programs. CEE is currently exploring program design options that are better adapted to a more competitive electric utility market. Golden Carrot programs face several challenges in the years ahead, including greater global competition in the manufacture and delivery of appliances. However, 
Golden Carrot programs also promise considerable energy and environmental benefits; and through innovation and flexibility, these programs may continue to produce socially beneficial results. 


\section{Contents}

$\underline{\text { Page }}$

Section 1. Introduction $\ldots \ldots \ldots \ldots \ldots \ldots \ldots \ldots \ldots \ldots \ldots \ldots \ldots \ldots$

Purpose and Organization of Report $\ldots \ldots \ldots \ldots \ldots \ldots \ldots \ldots \ldots$

DOE R\&D and Energy Efficiency Standards Programs for R/Fs ... . . . . . . . 3

DOE Advanced Refrigeration R\&D Program ................ 4

Energy Consumption Standards for R/Fs ................ 5

From Idea to Institution: Building the Framework for a Golden Carrot Program $\quad 8$

Section 2. Developing a Golden Carrot Program for Super-Efficient Refrigerators . . . . . 12

Section 3. The SERPTM, Inc. Competition and Program Implementation . . . . . . . 15

The SERPTM, Inc. Competition from Whirlpool's Perspective $\ldots \ldots \ldots \ldots \ldots$

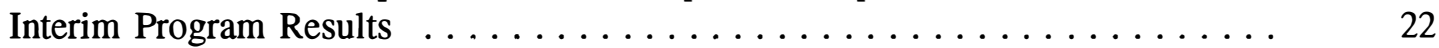

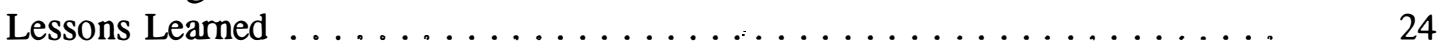

Section 4. CEE Golden Carrot Initiatives $\ldots \ldots \ldots \ldots \ldots \ldots \ldots \ldots \ldots \ldots \ldots \ldots \ldots \ldots$

Section 5. Legislative and Federal Support for Golden Carrot Programs . . . . . . . . 28

Report to Congress on Candidate Technologies for Development and

Commercialization Programs and Proposed Action Plan . . . . . . . . . . . . 28

CC.AP Action \#6: Form "Golden Carrot" Market-Pull Partnerships . . . . . . . . 28

CCAP Action \#13: Establish Golden Carrot Programs for

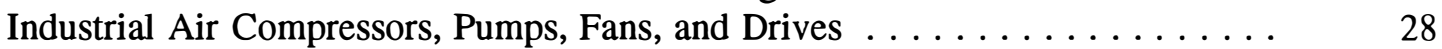

DOE Partnerships for Technology Introduction . . . . . . . . . . . . . . . 29

DOE Motor Challenge Program with Market Transformation Strategies . . . . . 30

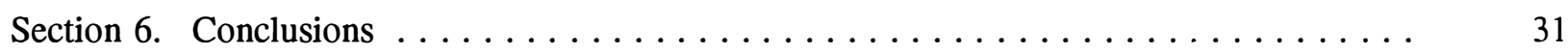

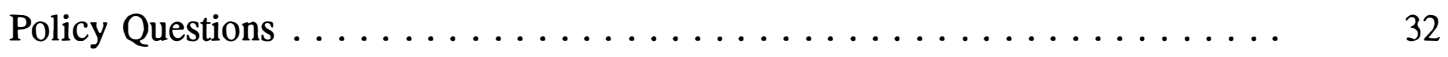

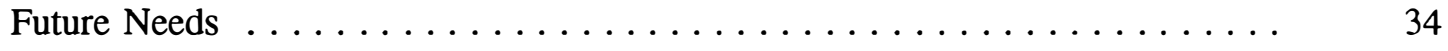

Bibliography $\ldots \ldots \ldots \ldots \ldots \ldots \ldots \ldots \ldots \ldots \ldots \ldots \ldots \ldots \ldots \ldots \ldots \ldots$

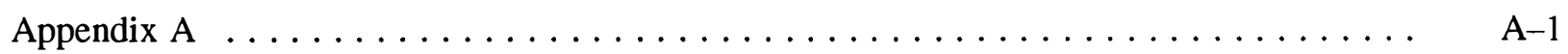

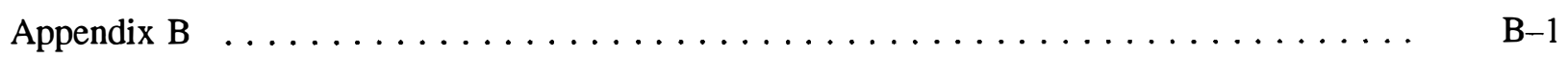




\section{List of Figures ;}

Page

1 Average annual unit energy consumption of R/Fs in kilowatt-hours, 1972-1993 ${ }^{\prime} \ldots \ldots \ldots$

2 Energy consumption of 1989 R/Fs relative to 1990 and 1993'

federal energy efficiency standards for $\mathrm{R} / \mathrm{Fs} \ldots \ldots \ldots \ldots \ldots \ldots$

3 Actual and projected improvement in R/F average efficiency, $1970-2010 \ldots \ldots$

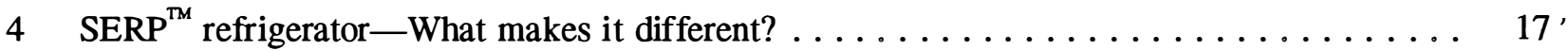

$5 \quad$ Kilowatt-hours per year consumed by SERPTM units $\left(22 \mathrm{ft}^{3}\right.$, side-by-side with through-the-door features) compared with NAECA standards $\ldots \ldots \ldots \ldots \ldots \ldots \ldots \ldots$ 18

6 Geographic distribution of SERPTM, Inc. utility service territories $\ldots \ldots \ldots \ldots \ldots \ldots \ldots$

7 Examples of newspaper headlines on the $\operatorname{SERP}^{\mathrm{TM}}$, Inc. competition $\ldots \ldots \ldots \ldots \ldots \ldots$ 23 


\section{List of Tables}

$\underline{\text { Page }}$

1 DOE Advanced Refrigeration R\&D $(1979-1998) \ldots \ldots \ldots \ldots \ldots \ldots$

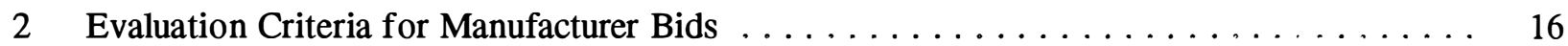

3 Estimated Total Energy and Environmental Savings from SERP ${ }^{\mathrm{TM}}$ Units $\ldots \ldots \ldots \ldots$

4 Whirlpool's Assessment of the Pros and Cons of Participating

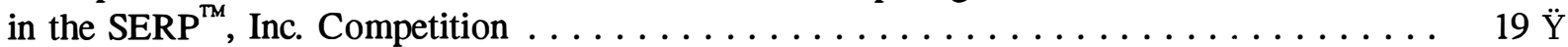




\section{Section 1. Introduction}

Manufacturer incentive programs, such as the Golden Carrot Super Efficient Refrigerator Program (SERP), are capturing attention from policy makers and utilities as possible cost-effective options for accelerating the production, commercialization, and sale of super-efficient, end-use technologies. The Golden Carrot concept is based on the premise that product manufacturers, responding to market-based incentives, could be stimulated to voluntarily accelerate the development and production of cost-effective, super-efficient end-use technologies - technologies that significantly exceed energy efficiency baselines established by National Appliance Energy Conservation Act (NAECA) standards. These incentives, used in tandem with federal appliance efficiency standards, could stimulate manufacturers to produce more energy-efficient, environmentally friendly products. By using this strategy, a Golden Carrot program could create new and enduring markets for super-efficient technologies.

The Golden Carrot concept first emerged in the late 1980s amid debates over the 1990 NAECA standards. Observers of the standards development process began exploring new approaches to increasing appliance efficiency that relied on incentives (the "carrot") rather than on the "stick" of compulsory standards. However, it was not until the promulgation of the 1993 federal appliance standards that interested individuals began to forge a Golden Carrot program. Although the 1993 standards were significantly more stringent than 1990 NAECA standards, many thought that it was possible to maximize energy efficiency levels for refrigerator/freezers (R/Fs) beyond what 1993 standards required. In addition, the impending ban on chlorofluorocarbons (CFCs) in manufacturing by 1996 provided an opportunity to fashion a program that combined the energy efficiency gains with the challenge of CFC substitution.

In 1990, representatives from utilities, environmental and energy groups, and federal and state governments convened to draft a plan for a Golden Carrot R/F program. In 1991, the group expanded and, working under the aegis of the Super Efficient Refrigerator Program, Inc. (SERPTM, Inc.), utility consortium, helped to formalize the Golden Carrot program design. The following year, SERPTM, Inc. issued a request for proposals (RFP) that offered financial and market incentives to the refrigerator manufacturer that could develop and commercialize the most cost-effective, super-efficient refrigerator. The program allowed the winning manufacturer the lead time needed to develop and produce a prototype of the winning R/F model, offered a rebate to the manufacturer for each super-efficient refrigerator produced and sold, and offered the promise of publicity and a competitive edge in the market for super-efficient refrigerators.

During its brief history, SERP has been described in various ways. When the program was first introduced to the public, it was referred to as a "long-term demand-side management (DSM) program" and a "technology commercialization and demonstration program" (L'Ecuyer et al. 1992, p. 5.137; Energy Policy Act of 1992. Title I, Subtitle C, Section 127). Since that time, it has been popularly referred to as a "market pull," and more recently, as a "market transformation" program (Goldstein 1994, p. 6.94; Feist et al. 1994, p. 3.69; Feldman 1994, p. 8.40; Nadel and Geller 1994, p. 10.187). "Market pull," as it is used in the literature on SERP and other Golden Carrot programs, generally describes an incentive offered to manufacturers (Clinton and Gore 1993; Feist et al. 1994, p. 3.73; Feldman 1994, p. 3.45). ${ }^{1}$ The specific definition of "market transformation" is still being discussed. However, parties to the debate generally agree on several general characteristics of current market transformation programs: (1) market transformation programs seek to spur voluntary commercialization and widespread availability of new, highly efficient technologies, or technologies that were minimally available; (2) the focus of most of these

${ }^{1}$ According to White and Wheat $(1994$, p. 1), the term "market pull" refers to incentives offered to consumers. However, market pull, as it is used in the literature on Golden Carrot incentives and in this paper, refers to incentives offered to manufacturers or other intermediaries. 
programs is on the producer of the technology; (3) market transformation programs seek long-term program impacts, and; (4) market transformation strategies vary and may incorporate a variety of strategies (for example, incentives to consumers, $\mathrm{R} \& \mathrm{D}$, codes and standards, and commercialization incentives) (Feldman 1994, pp. 8.39, 8.4; Goldstein 1994, pp. 6.91, 6.93; Nadel and Geller, pp. 10.187, 10.191).

Market-pull programs such as SERP depend on the voluntary participation of manufacturers to achieve their efficiency goals. However, it is debatable whether incentives alone would have encouraged manufacturer participation in the program. The term "market pull" may have evolved in the context of policy discussions in which voluntary programs were contrasted with mandatory efficiency standards programs and with "technology push," which emphasized producing technology with the assumption that the market would pick it up. ${ }^{2}$

Designers of SERP cite several advantages to the Golden Carrot approach. First, the administrative costs for a centrally administered incentive program are lower than for programs administered by individual utilities (Feist et al. 1994, p. 3.69; Farhang cited in Eckert 1994a, p. 3; Vine et al. 1994). The financial incentive, the guarantee of a sizable market, and the promise of positive publicity and product promotion induce manufacturers to develop more efficient product lines. Golden Carrot strategies such as SERP appear to eliminate many of the barriers to market change inherent in utility incentive programs to consumers. These barriers include free ridership, ${ }^{3}$ deterrents to manufacturers such as programs of short duration, limited product markets, and inconsistency among utility-endorsed product efficiency levels. Finally, the skills required to develop and administer an incentive program for product manufacturers-such as strategic planning, advocacy, facilitation, and partnership building/collaboration with utilities, federal and state governments, environmental groups, and others-have not commonly been found in the utility industry.

Federal policy makers are paying increased attention to market-pull strategies such as the Golden Carrot. Clinton Administration projections of program impacts indicate that Golden Carrot programs could significantly increase the energy efficiency of industrial, commercial, and residential end-use technologies, serve as catalysts for long-term changes in market values and behavior, stimulate private-sector investment, promote the development of public/private partnerships, and, through the use of super-efficient technologies, decrease greenhouse gas emissions in accordance with the Climate Change Action Plan (CCAP) (Clinton and Gore 1993 [Action Descriptions, pp. 7, 13]).

Golden Carrot programs such as SERP and subsequent initiatives offer a new approach to using incentives. These programs target their incentives at manufacturers (rather than consumers), rely on the participation of a group of utilities, and look toward long-term efficiency gains. In addition, no direct application of federal funds is needed to support Golden Carrot programs; federal contributions either provide in-kind technical assistance or are directed toward areas such as program evaluation or program design.

The U.S. Department of Energy's (DOE's) Office of Building Technologies also seeks to promote energy efficiency in residential and commercial buildings, by discovering new and innovative ways to develop and deploy such advanced program options as those advocated by the Golden Carrot concept.

\footnotetext{
2The name "Golden Carrot" evokes an image of the carrot dangling in front of the donkey to get it to move forward along the path; federal appliance efficiency programs may have been seen as a "stick." In fact, refrigerator manufacturers requested that the federal government issue energy consumption standards for refrigerator freezers (see section on DOE appliance efficiency standards).

${ }^{3} \mathrm{~A}$ free rider is a program participant who received an incentive to purchase an energy efficiency technology (for example, a geothermal heat pump, nonincandescent lighting, or other energy-saving technology), but who would have purchased the technology without the incentive.
} 
However, though Golden Carrot programs may provide policy makers with a new set of program options, they also raise a number of policy questions. For example, is providing incentives to manufacturers a more effective approach than providing tax credits to consumers in fostering efficiency in residential buildings? Are voluntary "winner-take-all" competitions more effective in sparking manufacturer creativity and commitment to production of energy-efficient appliances than mandatory federal appliance standards? Or are both needed? How was the program actually designed and carried out? What problems were encountered and how were they resolved? Is this type of program transferable to other industries and technologies? To what extent can utilities be counted on to support future Golden Carrot initiatives? Should the government's role in Golden Carrot programs be expanded? What are the measures for success for a Golden Carrot program?

There is still much to be learned about the viability and long-term impacts of these programs. Firm conclusions cannot be drawn until more Golden Carrot programs have been implemented and comprehensively analyzed. An interim evaluation of the SERP program is expected in the summer of $1995^{4}$; data on long-term results will not be available for several years.

\section{Purpose and Organization of Report}

This study, which is intended to foster more understanding of one innovative manufacturer incentive program, is based on a variety of published and unpublished documents, including the minutes of the Golden Carrot Executive Committee meetings, field notes from observing Golden Carrot Executive Committee meetings, federal documents, research reports, conference papers, journal and newspaper articles, transcripts from radio interviews, and interviews with key players.

The report consists of six sections. The first section provides an historical overview of DOE's R\&D and appliance standards programs. A discussion of the development and implementation of the Super-Efficient Refrigerator Program follows in the second section. The third section discusses the SERP competition and program implementation. The fourth section describes Golden Carrot initiatives launched by the Consortium for Energy Efficiency (CEE), and the fifth section, legislative and federal support for Golden Carrot programs. The final section reports interim program results and concludes with a brief discussion of several policy questions raised by the SERP model.

\section{DOE R\&D and Energy Efficiency Standards Programs for R/Fs}

During the past 22 years, refrigerator energy consumption has decreased significantly (see Figure 1). In addition to early influences such as rising electricity costs, energy-conscious consumers, and manufacturer efforts to improve product efficiency, this decline can be linked to DOE's Advanced Refrigeration R\&D Program results and to its promulgation of mandatory energy efficiency standards for R/Fs.

\footnotetext{
${ }^{4}$ Mark Ledbetter of Pacific Northwest Laboratory is conducting the interim evaluation of the SERPTM, Inc. Program.
} 


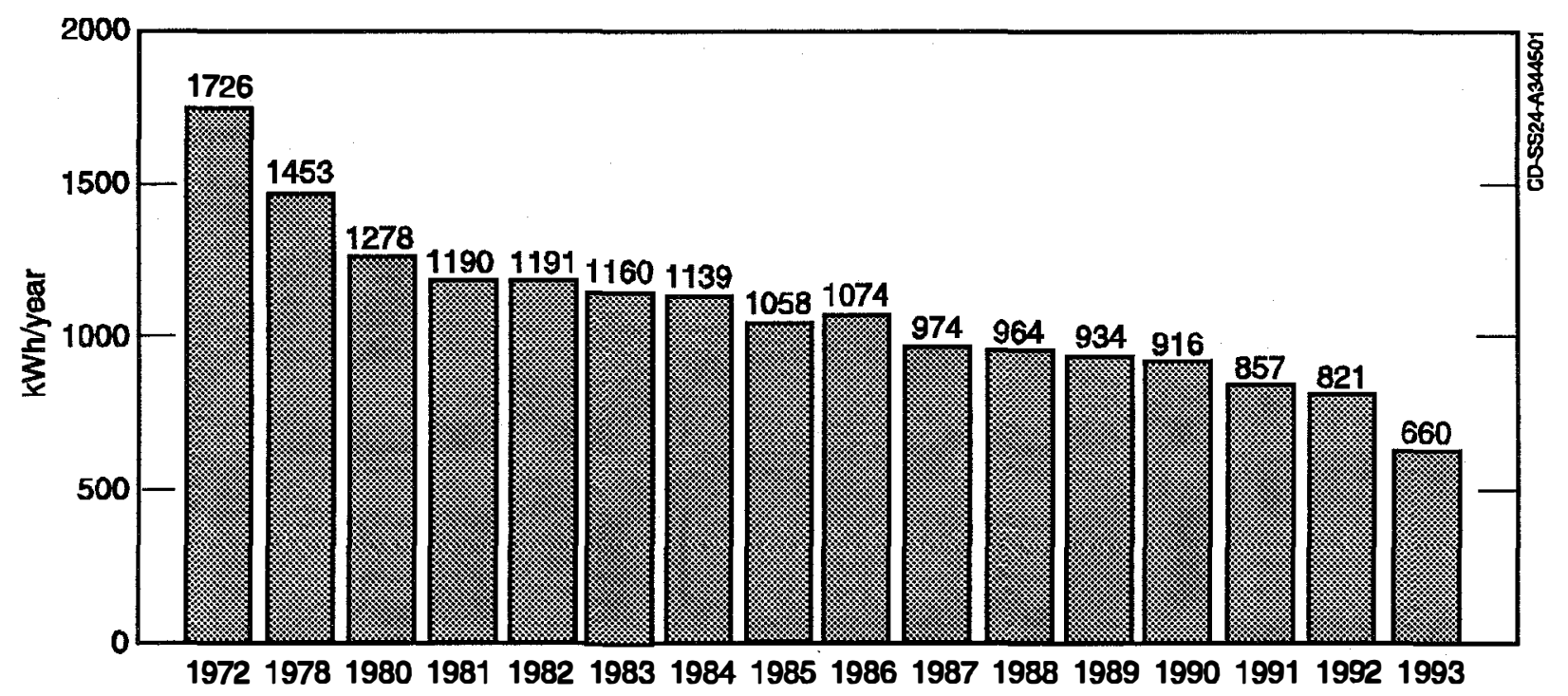

Source: Association of Home Appliance Manufacturers data.

Note: $R / F$ adjusted volume ranged from $18.16 \mathrm{ft}^{3}$ in 1972 to $20.51 \mathrm{ft}^{3}$ in 1984 to $20.11 \mathrm{ft}^{3}$ in 1993 . The median $\mathrm{R} / \mathrm{F}$ volume was $19.84 \mathrm{ft}^{3}$.

Figure 1. Average annual unit energy consumption of R/Fs in kilowatt-hours, 1972-1993

\section{DOE Advanced Refrigeration R\&D Program}

DOE support for refrigerator R\&D spans more than a decade. Table 1 shows that DOE was investigating energy efficiency options for R/Fs as early as 1979. Under a DOE-supported project managed by Arthur Little, Inc., Amana Refrigeration, Inc., developed and tested an R/F that used less than $2 \mathrm{kWh}$ per day (or fewer than $730 \mathrm{kWh}$ per year). DOE evaluated the unit and initiated a field demonstration to test the marketability and performance of Amana's energy-efficient R/F. This early DOE research focused on developing a high-efficiency motor/compressor. During 1983, DOE worked to strengthen cooperation with the refrigeration industry to develop more energy-efficient $\mathrm{R} / \mathrm{F}$ technologies and launched several joint R\&D and technology transfer projects (DOE no date [a], p. 3.2.4.2). By 1985, DOE was conducting R\&D in several key research areas that included nonazeotropic refrigerant mixtures, advanced insulation for refrigeration systems, and computer programs for advanced design concepts (DOE no date [a], p. 3.2.5.14).

In the mid-1980s, the Advanced Refrigeration Systems program budget increased markedly. Between 1986 and 1987, the projected fiscal year (FY) 1989 program budget more than doubled, increasing from $\$ 2$ to $\$ 5$ million. (DOE Office of Conservation 1987, pp. 3-49; DOE OBCS no date [b], p. 3). The additional funds allocated supported two new R\&D initiatives- the development of CFC substitutes and vacuum panel insulation. ${ }^{5}$ With the signing of the Montreal Protocol on substances that deplete the ozone

${ }^{5}$ Between 1986 and 1989, the Office of Building and Community Systems (OBCS, the Office of Building Technologies' precursor) assigned an increasingly higher priority to advanced refrigeration systems R\&D, elevating the program's ranking from \#20 (out of 45 programs) in 1986 to \#2 (out of 25 programs) in 1988. DOE promoted research on substitutes for CFCs to a \#3 priority rating. OBCS 
layer in January 1989, the search for CFC alternatives remained a high priority. ${ }^{6}$ In addition, DOE refrigeration $R \& D$ encompassed other applications such as the development of advanced heat pump, airconditioning, and commercial refrigeration technologies (DOE no date [c], p. 2-1, pp. 2-11-2-13).

As Table 1 shows, DOE's R\&D program contributed significantly to the body of scientific and technical knowledge that made possible the development of a super-efficient R/F. Several features incorporated into) the SERP ${ }^{\mathrm{TM}}$ model have their genesis in DOE-sponsored $\mathrm{R} / \mathrm{F} R \& D$. DOE is continuing to support advanced refrigeration research; DOE's 1996 budget request included support to continue (1) fundamental research on refrigeration technologies that will enable the refrigeration and air-conditioning manufacturers to develop equipment using new, nonchlorine-containing refrigerants, and (2) analysis of nonazeotropic refrigerant mixtures having potential for higher operating efficiency with heat pumps. DOE is currently testing advanced design concepts for a super-efficient refrigerator. By the end of FY 1995, DOE plans to complete laboratory evaluation of this $\mathrm{R} / \mathrm{F}$ under a cooperative $\mathrm{R} \& \mathrm{D}$ agreement with an appliance industry consortium, and to identify potential industry partners to pursue design and fabrication of the units for marketing (DOE 1995 [budget request], pp. 252-253).

\section{Energy Consumption Standards for R/Fs}

Until 1990, no federal energy conservation standards existed for R/Fs. Only California had promulgated energy efficiency requirements for R/Fs. ${ }^{7}$ In 1982, Whirlpool's line of R/Fs surpassed the California minimum standards by an average of $15 \%$ (Fang, Balistocky, and Schaefler 1982, p. 7.7).

The 1975 passage of the Energy Policy and Conservation Act (EPCA)(P.L. 94-163) was the first move toward federal regulation of R/F efficiency. Under the authority of EPCA, as amended by the National Energy Conservation Policy Act (NECPA) of 1976 (P.L. 95-619), DOE began the process of promulgating energy conservation standards for 13 consumer products, including R/Fs. ${ }^{8}$ EPCA specified that the

based its prioritization of $R \& D$ programs on a cost-benefit analysis that considered (1) the energy-savings potential of a project in the years 1995 and 2010; (2) potential oil savings in 2010; (3) consumer cost savings; (4) international competitiveness; and (5) environmental and health impacts (DOE 1987, pp. 3-40-3-41).

${ }^{6}$ The 1989 agreement, which was signed by most of the industrialized nations, called for a $50 \%$ reduction in CFC use by 1992 relative to 1986 levels. The Copenhagen Agreement, which is pending ratification, calls for a complete phase-out of CFC use by January 1, 1996 (DOE/EIA 1994c).

${ }^{7}$ The California Energy Commission first adopted standards for R/Fs in November 1977. These were updated in November 1979 and again in 1984; Geller 1986, p. 6.27; Morairty cited in Eckert 1995; p. 2.

${ }^{8}$ The procedure for prescribing new or amended standards entailed: (1) publishing an Advance Notice of Proposed Rulemaking (ANOPR), which specifies the type (or class) of covered products to which the rule may apply; (2) inviting interested persons to submit, within 60 days after the date of publication of the ANOPR, written data, views, and arguments in response to the notice. (DOE considers these comments when preparing the Notice of Proposed Rulemaking); (3) publishing the NOPR; (4) inviting interested parties, within 60 days of the NOPR's publication, to present oral and written comments pertaining to the notice. During this time, hearings are held in Washington, D.C. The comments received during this period are incorporated into the final rule; and (5) publishing a final rule prescribing an energy conservation standard for a covered product (EPCA as amended, Title III, Part B, Section 325p). 
Table 1. DOE Advanced Refrigeration R\&D* (1979-1998)

\begin{tabular}{|c|c|c|c|c|c|}
\hline $1979-1983$ & $1988-1992^{\star \star}$ & 1989-1993 & 1990-1994 & 1991-1994 & 1994-1998 \\
\hline$\because$ & . & $\begin{array}{l}\text { Identify, } \\
\text { characterize, and } \\
\text { test alternatives to } \\
\text { CFC-based } \\
\text { refrigerants in } \\
\text { compression-cycle } \\
\text { refrigerating } \\
\text { systems }\end{array}$ & $\begin{array}{l}\text { Identify, develop, } \\
\text { and test alternative } \\
\text { refrigerant fluids to } \\
\text { replace CFCs }\end{array}$ & $\begin{array}{l}\text { Research, develop, } \\
\text { and test alternatives } \\
\text { to CFC refrigerant } \\
\text { fluids and foam } \\
\text { insulation }\end{array}$ & $\begin{array}{l}\text { Develop CFC } \\
\text { alternatives; } \\
\text { complete material } \\
\text { compatibility } \\
\text { program for non- } \\
\text { CFC refrigerants; } \\
\text { complete HCFC } \\
\text { assessment (1993) }\end{array}$ \\
\hline 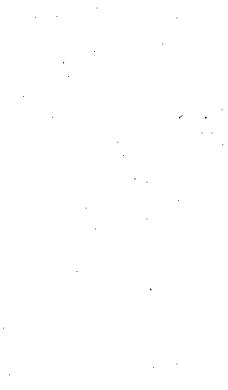 & $\begin{array}{l}\text { Research on } \\
\text { advanced insulation } \\
\text { concepts; develop } \\
\text { evacuated } \\
\text { insulation panels } \\
\text { that are cost- } \\
\text { effective, } \\
\text { structurally sound, } \\
\text { and capable of } \\
\text { maintaining a } \\
\text { vacuum }\end{array}$ & $\begin{array}{l}\text { Develop, evaluate, } \\
\text { and test alternative } \\
\text { designs, materials, } \\
\text { manufacturing } \\
\text { techniques, and } \\
\text { vacuum-sustaining } \\
\text { methods for } \\
\text { advanced appliance } \\
\text { insulation }\end{array}$ & $\begin{array}{l}\text { Develop, evaluate, } \\
\text { and test alternative } \\
\text { designs, materials } \\
\text { manufacturing } \\
\text { techniques, and } \\
\text { vacuum-sustaining } \\
\text { methods for } \\
\text { advanced appliance } \\
\text { insulation }\end{array}$ & $\begin{array}{l}\text { Develop, evaluate, } \\
\text { and test evacuated } \\
\text { insulation panels } \\
\text { that are cost- } \\
\text { effective, } \\
\text { structurally sound, } \\
\text { and capable of } \\
\text { maintaining an } \\
\text { acceptable vacuum } \\
\text { over } 15 \text { to } 20 \text { years }\end{array}$ & $\begin{array}{l}\text { Complete } \\
\text { development of } \\
\text { vacuum panel } \\
\text { technology (1993), } \\
\text { retrofit insulation, } \\
\text { and evacuated } \\
\text { powder panel } \\
\text { insulation (1997) }\end{array}$ \\
\hline & $\begin{array}{l}\text { Research on non- } \\
\text { azeotropic } \\
\text { refrigerant mixtures } \\
\text { (NARMS) in } \\
\text { refrigeration cycles }\end{array}$ & $\begin{array}{l}\text { Research on } \\
\text { applying NARMS } \\
\text { in refrigeration } \\
\text { cycles }\end{array}$ & $\begin{array}{l}\text { Evaluate several } \\
\text { new NARMS; } \\
\text { conduct basic heat- } \\
\text { transfer research on } \\
\text { NARMS }\end{array}$ & $\begin{array}{l}\text { Research } \\
\text { innovative } \\
\text { refrigeration cycles } \\
\text { based on NARMS }\end{array}$ & \\
\hline & $\begin{array}{l}\text { Develop capacity } \\
\text { modulation } \\
\text { techniques }\end{array}$ & $\begin{array}{l}\text { Develop capacity } \\
\text { modulation } \\
\text { techniques }\end{array}$ & $\begin{array}{l}\text { Develop capacity } \\
\text { modulation } \\
\text { concepts }\end{array}$ & & \\
\hline & $\begin{array}{l}\text { Develop computer } \\
\text { programs for } \\
\text { advanced design } \\
\text { concepts }\end{array}$ & & & & \\
\hline $\begin{array}{l}\text { Develop and test } \\
\text { high-efficiency } \\
\text { motor/compressor } \\
\text { for refrigerators }\end{array}$ & $\begin{array}{l}\text { Research } \\
\text { underlying } \\
\text { thermodynamics of } \\
\text { Rankine cycle; } \\
\text { investigate and } \\
\text { evaluate novel } \\
\text { concepts related to } \\
\text { vapor compression } \\
\text { systems }\end{array}$ & $\begin{array}{l}\text { Research the } \\
\text { dynamic losses } \\
\text { associated with } \\
\text { electrically-driven } \\
\text { refrigeration } \\
\text { systems, and } \\
\text { develop advanced } \\
\text { concepts to reduce } \\
\text { these losses }\end{array}$ & & $\begin{array}{l}\text { Continue } \\
\text { exploratory work } \\
\text { including a new } \\
\text { study of a liquid } \\
\text { overfeed evaporator } \\
\text { refrigeration system } \\
\text { to eliminate system } \\
\text { inefficiency } \\
\text { associated with } \\
\text { refrigerant } \\
\text { superheat; complete } \\
\text { laboratory } \\
\text { evaluation under } \\
\text { CRADA with } \\
\text { appliance industry } \\
\text { consortium on R/F } \\
\text { and identify } \\
\text { potential industry } \\
\text { partners to pursue } \\
\text { market entry by } \\
1998\end{array}$ & $\begin{array}{l}\text { Develop cost- } \\
\text { effective } \\
\text { microcogeneration } \\
\text { systems; research } \\
\text { and develop gas- } \\
\text { cycle refrigerator } \\
\text { by } 1997\end{array}$ \\
\hline
\end{tabular}

Source: DOE OBCS/OBT Energy Conservation Multi-Year Plans (MYPP).

*DOE has explored application of this R\&D to heat pumps, air conditioners, and other refrigeration technologies. **MYPPs were not available for 1984-1988.

Note: The MYPP "is an internal [DOE] document that represents one stage of an ongoing process to analyze and evaluate programs and to plan for the future. The document in not a budget submission but a planning tool used to set programs' technical priorities and policy over at least a five-year period" (DOE 1987, pp. 1-5). 
conservation standards achieve the maximum energy or water efficiency levels that were technologically feasible and economically justified (EPCA, Title III, Part B, Section 325[n-o]). ${ }^{9}$ When developing these initial standards, DOE was unable to provide assurances to manufacturers that proprietary data could be protected from public disclosure. This thwarted the collection of data crucial for developing the technical and economic analyses necessary for establishing standards (DOE 1979, p. 8-1). Initially, trade associations collected and aggregated manufacturer data which was, in turn, provided to DOE. DOE published a Notice of Proposed Rulemaking (NOPR) on energy conservation standards for 13 consumer products in the Federal Register and received comments, but was unable to meet the statutory deadline for issuing a final ruling.

From 1980 to 1982, DOE reevaluated the public comments received in response to the NOPR as well as the Department's economic and engineering analyses. On April 2, 1982, DOE issued a new NOPR for efficiency standards for eight of the 13 products covered by the legislation. ${ }^{10}$ After reviewing the comments submitted in response to this NOPR, the Department concluded that energy conservation standards would not result in significant energy savings and would not be economically justified. Therefore, DOE proposed a "no standards" ruling for each of the eight products (Fang, Balistocky, and Schaefler 1982, p. 1.1). Under EPCA, this rule would take precedence over existing state standards that applied to the products addressed in the rule (EPCA as amended by NECPA, Section 327).

The "no standards" ruling sparked a heated debate among states, manufacturers, and public interest groups. Appliance manufacturers were concerned that there would be no uniformity if state energy efficiency standards prevailed. They argued that complying with varying standards would fragment the market; necessitate multiple production, distribution, and warehousing facilities; necessitate multiple marketing materials and training programs for sales and service personnel; result in a proliferation of test procedures; and require expanded $R \& D$ programs. These burdens would increase manufacturer costs, impede company growth, adversely affect smaller manufacturers, and place U.S. manufacturers at a disadvantage relative to nonregulated foreign producers (Fang, Balistocky, and Schaefler, pp. 2.2, 2.13, 6.13, 6.15). The

\footnotetext{
${ }^{9}$ To determine whether a standard is economically justified, DOE must consider: (1) the economic impact of the standard on the manufacturers and the consumers; (2) the savings in operating costs throughout the estimated average life of the covered product compared to any increase in the price of the covered product; (3) the total projected amount of energy or water savings likely to result from imposing the standard; (4) any lessening of the utility or the performance of the covered product; (5) the impact of any lessening on competition; (6) the need for national energy and water conservation, and (7) other factors deemed relevant.

If DOE finds that the additional cost to the consumer of purchasing a product complying with an energy conservation standard level will be less than three times the value of the energy or water savings during the first year, as calculated under the applicable test procedure, then the standard shall be considered economically justified (EPCA as amended, Part II, Part B, Section 325n). This amounts to a payback period of less than three years.

The SERP process resulted in a significant change in the way standards are negotiated. In an unprecedented concurrence of opinion, manufacturers, energy organizations, and other stakeholders developed and agreed on proposed 1998 standards for R/Fs. DOE is currently reviewing the proposal but preliminary indications are that few changes will be made. A NOPR is scheduled to be published in the Federal Register in late May or June 1995.

${ }^{10}$ The eight products were (1) refrigerators and refrigerator/freezers, (2) freezers, (3) clothes dryers, (4) kitchen ranges, (5) ovens, (6) water heaters (not including heat pump water heaters), (7) room air conditioners, and (8) central air conditioners (excluding heat pumps and furnaces) (Fang et al. 1982, p.1.1).
} 
majority of appliance manufacturers commenting on the proposed rule favored federal preemption of state and local standards and implicitly pressed for federal efficiency standards.

In 1987, Congress passed the National Appliance Energy Conservation Act (NAECA) (P.L. 100-12). ${ }^{11}$ NAECA amended EPCA and mandated that DOE promulgate standards for 13 consumer products by dates specified in the statute. ${ }^{12}$ The statute also required that, at the same time, DOE develop revised $1990 \mathrm{R} / \mathrm{F}$ standards. DOE completed the regulatory review process and on January 1, 1990, NAECA standards for $\mathrm{R} / \mathrm{Fs}$ took effect. NAECA specified that if DOE did not publish a final rule revising 1990 NAECA standards before January 1, 1990, the State of California's December 14, 1984, standards would become effective in California beginning January 1, 1993. Furthermore, California's standards could not be preempted by any federal standard until the state made them more stringent (DOE Office of Conservation and Renewable Energy 1989, pp. 47,918-47,919).

On November 17, 1989, DOE published a final rule in the Federal Register prescribing 1993 energy conservation standards for ten classes of refrigerators, R/Fs, and freezers. The 1993 standards were significantly more stringent than those promulgated for 1990 models, which only eliminated the most inefficient models from the market (DOE Office of Conservation 1987). Although DOE determined that the 1993 standards were "technologically feasible and economically justified," Figure 2 suggests that few manufacturers had pushed the limits of their technological capabilities to produce more efficient units. In fact, many manufacturers were marketing units that just met or fell below 1990 federal energy efficiency levels. ${ }^{13}$

Over the past five years, DOE federal efficiency standards have effected greater efficiency in R/Fs. Figure 3 shows the sharp decrease in average R/F energy consumption following promulgation of the 1993 standards and the additional efficiency gains anticipated consequent to the 1998 standards. An NOPR for 1998 is being prepared for publication in the Federal Register in late July or August 1995.

\section{From Idea to Institution: Building the Framework for a Golden Carrot Program}

The SERP Program first took shape in fall 1990 when representatives from the Pacific Gas and Electric Company (PG\&E), the Washington State Energy Office (WSEO), the Natural Resources Defense Council (NRDC), the American Council for an Energy Efficient Economy (ACEEE), and the U.S. Environmental

${ }^{11}$ Congress passed amendments to NAECA in 1988 (P.L. 100-357).

${ }^{12}$ The 13 consumer products covered by NAECA are (1) refrigerators, refrigerator/freezers, and freezers; (2) room air conditioners; (3) central air conditioners and central air-conditioning heat pumps; (4) water heaters; (5) furnaces; (6) dishwashers; (7) clothes washers; (8) clothes dryers; (9) direct-heating equipment; (10) kitchen ranges and ovens; (11) pool heaters; (12) television sets; and (13) fluorescentlamp ballasts.

${ }^{13}$ In the 1995 final rule, the Department established that the technology existed to support the production of super-efficient refrigerators; however, DOE found that a number of these energy efficiency technology options could not be "economically justified" (DOE 1989, pp. 47,919-47,920). Maximum, technologically feasible levels listed in the final rule included: automatic-defrost, top-mount, $20.8 \mathrm{ft}^{3}$ (490 kWh/yr); automatic-defrost, side-by-side, $24.1 \mathrm{ft}^{3}$ (564 kWh/yr); automatic-defrost, side-by-side with through-the-door service features, $31.9 \mathrm{ft}^{3}(746 \mathrm{kWh} / \mathrm{yr})$; automatic-defrost, top-mount with through-thedoor service features, $20.8 \mathrm{ft}^{3}$ (most comparable to the SERPTM unit) (540 kWh/yr) (DOE Office of Conservation 1989, p. 47,919). 


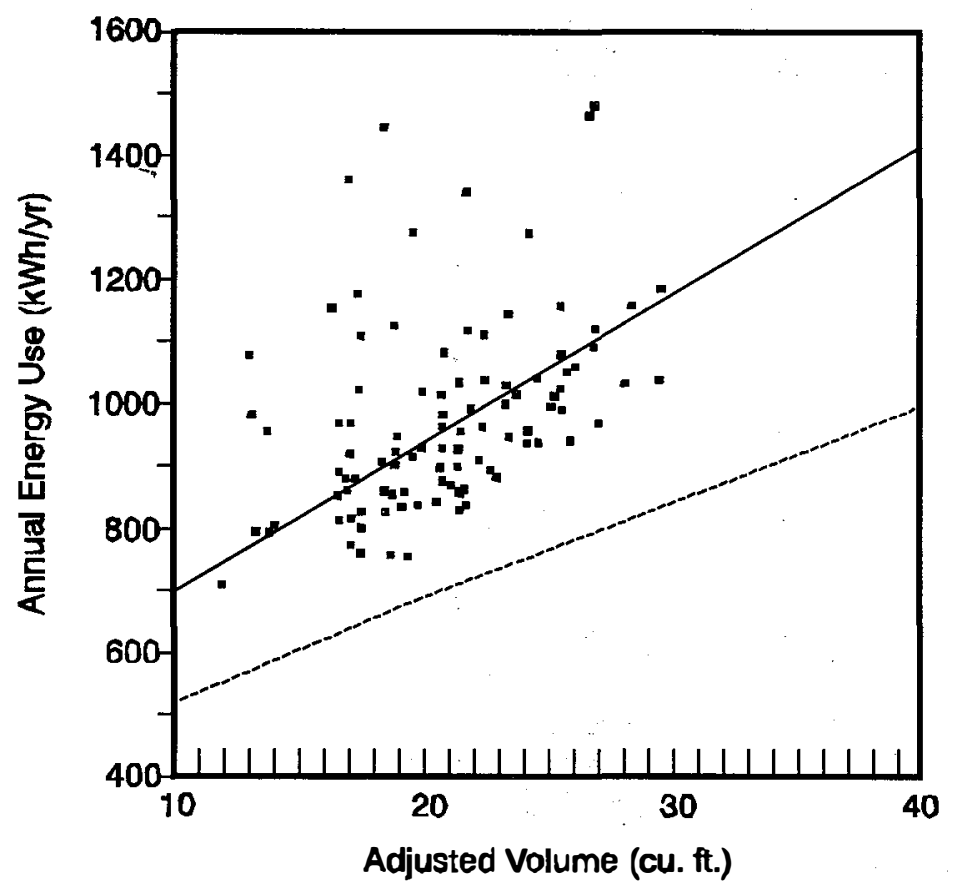

Source: Adapted from Turiel et al. 1990, p. 1.218.

Note: According to Isaac Turiel, the 1989 energy consumption pattern of side-by-side, automatic-defrost models relative to the 1990 and 1993 federal standards was similar to that of the top-mount R/Fs depicted in Figure 2 (Turiel cited in Eckert 1995f, p. 1).

\section{Figure 2. Energy consumption of $1989 \mathrm{R} / \mathrm{Fs}$ relative to 1990 and 1993 federal energy efficiency standards for R/Fs}

Protection Agency (EPA) met to discuss strategies for encouraging refrigerator manufacturers to develop and commercialize more efficient R/F technologies. Meeting participants developed a "strawman" proposal for a Golden Carrot program to spur production of super-efficient refrigerators. According to the proposal, a consortium of utilities would contribute funds to support a competitive bid program for refrigerator manufacturers. The consortium would award the bid pool to the refrigerator manufacturer producing the most efficient $\mathrm{R} / \mathrm{F}$.

In January 1991, PG\&E and WSEO sponsored the National Utility Workshop on Very Efficient Refrigerator Programs. The purpose of the workshop was to examine existing programs promoting refrigerator efficiency and to discuss developing a Golden Carrot program for refrigerators. Workshop participants included the Association of Home Appliance Manufacturers (AHAM), ACEEE, NRDC, EPA, DOE, and others.

Several Golden Carrot program proposals were considered at the workshop, including the "strawman" proposal developed in late 1990/early 1991 by PG\&E, WSEO, NRDC, ACEEE, and EPA. Workshop participants interested in the Golden Carrot concept formed the Golden Carrot Executive Committee. The committee met throughout 1991 to develop a plan for a Golden Carrot refrigerator program and to lay the foundation for other Golden Carrot initiatives (Fernstrom 1991; Association of DSM Professionals 1991). 


\section{Section 2. Developing a Golden Carrot Program for Super-Efficient Refrigerators}

Following the January 1991 Workshop on Very Efficient Refrigerator Programs, several Califomia utilities decided to form an organization to accelerate development of super-efficient refrigerators. Throughout the spring and summer of 1991, the utilities solicited the support of other public and private utilities. In September 1991, concomitant with the formation of CEE, this consortium of utilities incorporated SERPTM, Inc., a nonprofit organization that serves as the central administrative and decision-making body for the SERP Program. ${ }^{15}$ The objectives of SERPTM, Inc. are to

- Use existing market forces and provide incentives to manufacturers to design, develop, and distribute super-efficient R/Fs during the years 1994 to 1997

- Ensure that any R/F distributed under the program meets high standards for energy efficiency, pollution control, and consumer satisfaction

- Ensure that SERPTM R/Fs have adequate market appeal

- Ensure accountability in the program so that utility members can appropriately document relevant costs, kWh savings, and efficiency (Super Efficient Refrigerator Program, Inc. 1993).

Its membership - which is composed of electric and gas utilities, environmental and public interest groups, and government agericies-includes 40 utilities serving more than 25 million customers nationwide. The organization is funded by its members and receives federal contributions from DOE and EPA (Alexander cited in Farhar 1994, p. 5).

SERPTM, Inc. consists of an elected board of directors composed of representatives from eight member utilities. $^{16}$ The board formed seven committees to develop aspects of the Golden Carrot program. These committees involved approximately $30 \%$ of SERPTM, Inc. members and included participants from outside organizations (Farhang cited in Eckert 1994b). These seven included the Executive Committee, the Distribution and Tracking Committee, the Contract Negotiation Committee, the Contract Performance

${ }^{15}$ Located in 10 states, these utilities provide electricity to $21 \%$ of U.S. households (Treece 1993) (see Figure 6). The 24 utilities forming the SERPTM, Inc., consortium and their contributions are: Atlantic City Electric Company $(\$ 500,000)$; Arizona Public Service Company $(\$ 250,000)$; Bonneville Power Administration ( $\$ 2.1$ million); Baltimore Gas and Electric Company ( $\$ 1.425$ million); Central Maine Power $(\$ 301,500)$; Commonwealth Electric Company and Cambridge Electric Light $(\$ 500,000)$; Jersey Central Power and Light $(\$ 969,440)$; Long Island Lighting Company ( $\$ 1.944$ million); Los Angeles Department of Water and Power ( $\$ 2$ million); Madison Gas and Electric Company $(\$ 135,000)$; New England Electric System ( $\$ 1.5$ million); Northern California Power Agency $(\$ 128,444)$; Northern States Power Company-Wisconsin $(\$ 185,000)$; Northern States Power Company-Minnesota $(\$ 400,000)$; Pacific Gas and Electric Company (\$6.6 million); PacifiCorp ( $\$ 1$ million); Public Service Electric and Gas Company ( $\$ 3$ million); Sacramento Municipal Utility District $(\$ 750,000)$; Southern California Edison Company (SCE) (\$5.850 million); Superior Water, Light and Power Company $(\$ 13,600)$; Western Massachusetts Electric Company $(\$ 317,822)$; Wisconsin Electric Power Company $(\$ 200,000)$; Wisconsin Power and Light Company $(\$ 285,767)$; Wisconsin Public Service Corporation $(\$ 347,368)$ (Super Efficient Refrigerator Program 1993, p. 4).

${ }^{16}$ Board elections occur annually. SERPTM, Inc. members are allotted one vote per every $\$ 5,000$ contributed to the bid pool (Farhang cited in Eckert 1994b, p. 3). 
Subcommittee, the Joint Banking Committee, the Public Affairs Committee, and the Advisory Committee (formerly the Golden Carrot Executive Committee). ${ }^{17}$

During 1991 and early 1992, SERPTM, Inc. committees met to develop recommendations on program design and logistics. Committees worked by consensus. Each committee presented its recommendations before the SERPTM, Inc. board of directors, which decided on the recommendations by majority vote.

The Advisory Committee considered many of the issues previously addressed by the Golden Carrot Executive Committee. These included:

- The cost-effectiveness of utility participation and the level of utility risk

- The bid pool incentive

- The amount and timing of incentive payments

- An RFP time line and solicitation criteria

- The terms of manufacturer participation

- Program administration

- Product guarantees, liability, and patent rights

- Evaluation and monitoring protocols.

SERPTM, Inc. is funded entirely by consortium members. Participating utilities have contracted to pay, or deposit, incentive funds totaling more than $\$ 30$ million into a bid pool account that is centrally administered by SERPTM, Inc. ${ }^{18}$. SERPTM, Inc. is responsible for all financial transactions with the winning manufacturer and will carry out quality assurance and program evaluation on behalf of member utilities. $^{19}$ This structure was intended to reduce utility risk (L'Ecuyer et al. 1992, p. 5.142). If the manufacturer does not abide by the schedule and performance standards agreed on, the consortium may cancel the contract (Office of Atmospheric and Indoor Air Programs 1992, p. 26 of Appendix). In

${ }^{17}$ The Golden Carrot Executive Committee became the Golden Carrot Advisory Committee after the incorporation of SERPTM, Inc. In its advisory capacity, the committee issued recommendations on program design and implementation to the SERPTM, Inc. board of directors, but had no decision-making authority. The committee disbanded after the RFP phase of the refrigerator competition was completed (Farhang cited in Eckert 1994b, p. 1).

${ }^{18}$ Regulators in most states have not developed cost-recovery mechanisms for utilities investing in long-term DSM programs such as the SERPTM, Inc. refrigerator competition. California utilities participating in SERP ${ }^{\mathrm{TM}}$, Inc. received authorization from the California Public Utilities Commission to invest in the program with the provision that the utilities would be subject to a rate review every three years (Farhang cited in Eckert 1994b, p. 1). Several utilities requested regulatory approval to participate in SERPTM, Inc. in states where DSM incentives were not yet available (e.g., Florida, Pennsylvania, and Texas). Information on the mechanisms used by utilities to recover their costs was not available when this report was written.

${ }^{19} \mathrm{SERP}^{\mathrm{TM}}$, Inc. hired a firm specializing in contract management to manage the contract between the utilities and the manufacturer (Golden Carrot Executive Committee 1991d; Golden Carrot Executive Committee 1991c, pp. 1-2). 
(1) Net value of efficiency gain (76 points):

- Type and size of the unit or units bid

- Unit energy consumption

- Proposed schedule for deliveries

- Requested incentive per unit bid.

(2) Company reliability (22 points):

- Experience with the technologies proposed

- Marketing strategy

- Procedure for collecting customer sales information

- Corporate economic indicators

- Strength of the product warranty.

(3) Bonus ( 3 points): Bidders could receive up to three additional points for:

- Avoiding use of chlorine-bearing HCFC compounds in the refrigerant and the insulation (up to 2 points)

- Proposing models with no air movement between the freezer and the fresh food compartments (up to 1 point). J

Source: L'Ecuyer et al. 1992, pp. 5.141-5.142.

evaluators scored the finalists' bids based on the prototypes and, on June 29, 1993, SERPTM, Inc. announced Whirlpool the winner. By late December 1993, Whirlpool had batch-produced and delivered 40-50 field-test units to SERP ${ }^{\mathrm{TM}}$, Inc. for testing at a designated laboratory. In January 1994, Whirlpool began manufacturing white, side-by-side, $22-\mathrm{ft}^{3}$ units with the Whirlpool and Kitchen-Aid brands, and sold them through Sears stores under the Kenmore label (Newsday 1993, p. 41). By April 1994, Whirlpool began to deliver qualifying units to retailers in the service territories of participating utilities.

The winning Whirlpool unit was the result of many small technological improvements (see Figure 4). For example, by changing the shape of the drainpipe, Whirlpool engineers effected an efficiency gain of up to one percent. The adaptive defrost control using "fuzzy logic" software registered energy savings of 3.5 percent or greater.

SERPTM, Inc. units produced in 1994 were $22 \mathrm{ft}^{3}$, consumed about $670 \mathrm{kWh}$ per year, and were $29.7 \%$ more efficient than 1993 federal standards required ${ }^{27}$ (Atlanta Constitution 1993; Feist et al. 1994, p. 3.70; Anderson cited in Farhar 1994, p. 1) (see Figure 5). Estimated consumer electric bill savings per unit are approximately $\$ 330$ over the life of the R/F (see Appendix B). ${ }^{28}$ The SERP ${ }^{\mathrm{TM}}$, Inc. units use no CFCs. Whirlpool has replaced the refrigerant CFC-12, also known as Freon, with hydrofluorocarbon 134a (HFC134a) and CFC-11 (used as a blowing agent for the foam insulation), together with a highimpact polystyrene liner. Table 3 shows the estimated energy and environmental savings resulting from the SERP Program.

${ }^{27}$ The 1993 NAECA standard for a comparable model refrigerator is $953 \mathrm{kWh} /$ year.

${ }^{28}$ Whirlpool estimates that the cost of operating a 1994 SERPTM, Inc. 22- $\mathrm{ft}^{3} \mathrm{R} / \mathrm{F}$ at $670 \mathrm{kWh}$ per year is approximately $\$ 55.00$ per year, assuming $\$ 0.0825$ per $\mathrm{kWh}$ (Feist et al. 1994, p. 3.73). 


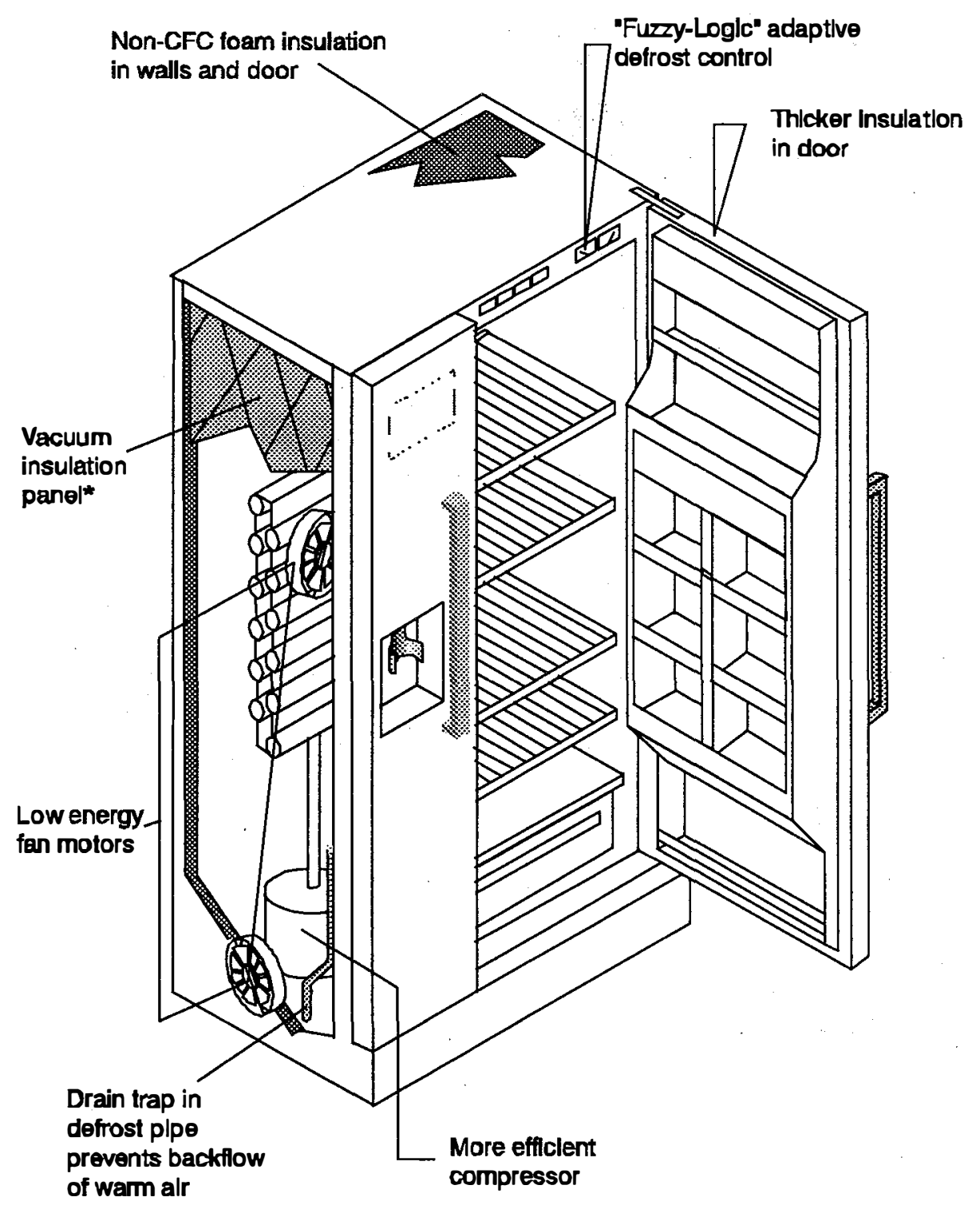

Source: Adapted from Whilpool Home Appliances news release. Not Intended to be an accurate representation of a SERP refingerator.

*Avallable $\mathrm{h} 1995$ models

Note: This figure is for illustrative purposes only and is not an exact depiction of an actual SERP unit.

Figure 4. SERP ${ }^{\mathrm{TM}}$ refrigerator-What makes it different? 


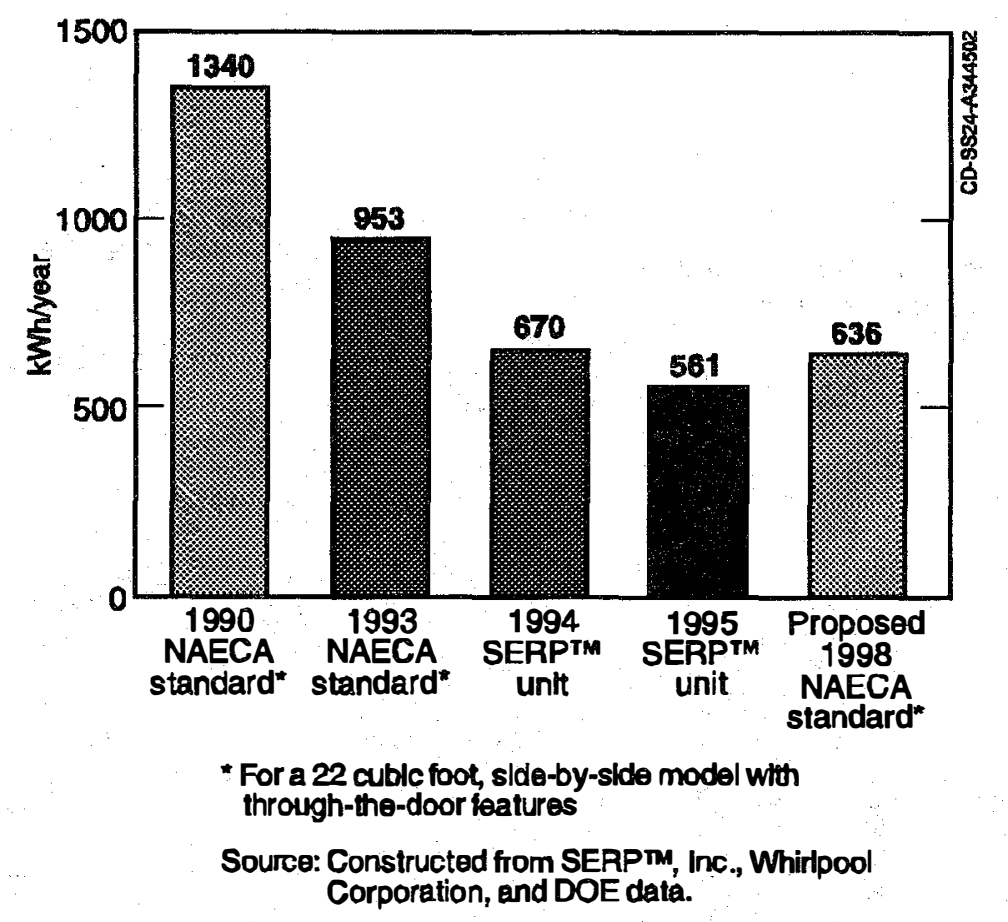

Note: See Appendix A for an explanation of NAECA R/F standards.

Figure 5. Kilowatt-hours per year consumed by SERPTM units $\left(22 \mathrm{ft}^{3}\right.$, side-by-side with through-the-door features) compared with NAECA standards

\section{The SERPTM, Inc. Competition from Whirlpool's Perspective}

Whirlpool Corporation, like many other refrigerator manufacturers, had doubts about participating in the SERP $^{\mathrm{TM}}$, Inc. competition (Farhang cited in Eckert 1994b, p.7). When Whirlpool executives first learned of the competition in 1990, the company was coping with slowing sales and preparing for the EPA ban on CFCs effective in 1993 (Treece 1993, p. 79). Table 4 outlines Whirlpool's assessment of the risks and benefits of participating in the SERP competition. They faced several challenges: developing a CFC-free, super-efficient refrigerator, developing a product complying with SERP specifications that would also be marketable to consumers, and meeting the development and production deadlines established by SERP $^{\mathrm{TM}}$, Inc.

Whirlpool did not identify the financial incentive as a lead selling point. ${ }^{29}$ Critical to them was the competition's potential to increase Whirlpool's market share. In 1992, Whirlpool was second in the

\footnotetext{
${ }^{29}$ In an interview with National Public Radio, Vince Anderson, Manager of Refrigeration Technology at Whirlpool Corporation, acknowledged that the $\$ 30$ million incentive was not the primary reason Whirlpool responded to the SERP solicitation. The company, he stated, invested several million dollars in its refrigeration $R \& D$ program during the several years preceding the competition and in 1993 had total sales of about $\$ 7$ billion. The $\$ 30$ million, he continued, does not amount to a "tremendous percentage of our total corporate sales." Anderson said the company will spend far more than $\$ 30$ million to retool its manufacturing plants and to produce the new refrigerators (Sanders 1993, p. 2).
} 
Table 3. Estimated Total Energy and Environmental Savings from SERPTM Units

Total utility investment: $\$ 30$ million

Total energy savings: $1,059,800 \mathrm{MWh}$ over 14 years

Total dollars saved on consumers' electric bills: $\$ 82,250,000$ over 14 years

Emissions reduced over 14 years:

- $\mathrm{CO}_{2}$ emissions reduced by 0.78 million metric tons

- $\mathrm{NO}_{\mathrm{x}}$ emissions reduced by 3,293 metric tons

- $\mathrm{SO}_{2}$ emissions reduced by 5,838 metric tons.

aThese figures represent the estimated impact of 250,000 22- $\mathrm{ft}^{3}$, side-by-side SERP units, assuming an average per-unit life of 14 years. The assumptions used in calculating these impacts will be revised as more data become available on the different types of SERP units produced and on their respective energy savings. See Appendix $B$ for assumptions and calculations on which the above figures are based.

Table 4. Whirlpool's Assessment of the Pros and Cons of Participating in the SERP $^{\mathrm{TM}}$, Inc. Competition

\begin{tabular}{l|l}
\multicolumn{1}{c|}{ Pros } & \multicolumn{1}{c}{ Cons } \\
\hline $\begin{array}{l}\text { Developing a super-efficient refrigerator was a } \\
\text { worthy objective. }\end{array}$ & $\begin{array}{l}\text { - The company had already improved the } \\
\text { efficiency of its product line so that it exceeded } \\
\text { DOE } 1990 \text { energy efficiency standards. }\end{array}$ \\
$\begin{array}{l}\text { - The competition provided a good incentive } \\
\text { because the company already had more advanced } \\
\text { models in progress. }\end{array}$ & $\begin{array}{l}\text { Meeting the efficiency challenge would be } \\
\text { difficult since non-CFC materials are less } \\
\text { efficient and were not as well known to } \\
\text { Whirlpool. }\end{array}$ \\
$\begin{array}{l}\text { - Even if the company lost, there was a lot to be } \\
\text { learned by participating in the process. }\end{array}$ & $\begin{array}{l}\text { The competition required a heavy up-front } \\
\text { investment. }\end{array}$ \\
$\begin{array}{l}\text { Whirlpool was in a strong position to participate; } \\
\text { the company had human and financial resources, } \\
\text { manufacturing capital, and a distribution system, } \\
\text { and could develop a super-efficient addition to its } \\
\begin{array}{l}\text { Kenmore line. } \\
\text { - There was a tight time frame for developing and } \\
\text { producing the super-efficient unit. }\end{array}\end{array}$ & $\begin{array}{l}\text { The company would have to meet consumer } \\
\text { expectations. }\end{array}$ \\
\hline
\end{tabular}

Source: Anderson cited in Farhar 1994, pp. 2-3. 
Anderson, would be a "marketing coup," giving the winner a distinct advantage over other manufacturers in being the first to get its product on the mass market (Sanders 1993, p. 2). This competitive aspect of the process proved to be a driving force for participating manufacturers.

In March 1992, Whirlpool Corporation formed two teams consisting of planners, accountants, lawyers, engineers, marketers, and accountants drawn from the corporation's U.S., European, and South American offices. $^{30}$ The first of these teams, the Golden Carrot Task Force, was a cross-functional team that served as a liaison with SERPTM, Inc. The task force identified resources, developed strategies, prepared the company's bid, and oversaw the process. The second team was a Prototype Team, responsible for engineering and building test models of the super-efficient unit. In April 1993, Whirlpool also established a Project Team to prepare the prototype for mass production, develop sales support materials, and activate a sales and tracking program. This team took over on June 29, 1993, when SERPTM, Inc. announced Whirlpool the winner. The Project Team will continue to function for the duration of the program (Anderson cited in Farhar 1994, pp. 3-4).

By August 1992, just four months before SERPTM, Inc. announced the finalists in the first round of the competition, Whirlpool had developed two prototypes: one relied on "wied-and-true" technologies, the other "pulled out all the stops." In the end, Whirlpool executives decided to submit the more aggressive bid, knowing that their submission would be judged against that of their primary competitor, GE.

Whirlpool is responsible for marketing and selling SERPTM units in participating utility territories (see Figure 6). Contract terms specify that Whirlpool deliver the units to dealers when promised and in numbers corresponding with each utility's financial commitment to the program. At the close of 1994, Whirlpool delivered approximately 34,000 units to qualifying retailers. SERPTM, Inc. pays Whirlpool a rebate of approximately $\$ 100$ for each unit sold to retailers (Anderson cited in Farhar 1994, p. 2; Feist et al. 1994, p. 3.70). Under the contract, Whirlpool must introduce the super-efficient R/Fs to retail distributors at wholesale prices commensurate with those of comparable, less efficient models (L'Ecuyer et al. 1992, p. 5.142). The retail value of SERPTM $R / F$ s ranges from $\$ 1,000$ to $\$ 1,400$ (Farhang cited in Eckert 1994b, p. 8; HFD—Retailing Home Furnishings 1993, p. 75).

Although Whirlpool has primary responsibility for marketing and selling the SERPTM R/Fs, a few utilities have taken an active role in promoting the units. For example, an informal survey of the largest SERPTM contributors revealed that three utilities offered cash incentives to consumers purchasing SERPTM R/Fs. ${ }^{31}$ One utility, PG\&E, discontinued its rebate program but is allowing eligible consumers to finance superefficient R/Fs through the utility's Energy Efficiency Loan program. Baltimore Gas \& Electric (BG\&E) is selling the R/Fs directly to consumers through the utility's retail sales outlets. In addition, AZ PSCo is considering buying SERP ${ }^{\mathrm{TM}}$ units and making them available to segments of the market in the utility's

\footnotetext{
${ }^{30}$ Whirlpool has plants in Michigan, Arkansas, Indiana, and Latin America that manufacture compressors, and plants in Europe that manufacture state-of-the-art foam insulation equipment.

${ }^{31}$ Eleven out of the 24 SERP ${ }^{\text {TM }}$ utilities were contacted by telephone to determine how many supplemented their rebates to Whirlpool with cash incentives to consumers. The utilities surveyed included LADWP, LilCo, SMUD, SCE, PG\&E, Arizona Public Service Company (AZ PSCo), New England Electric System (NEES), BG\&E, Wisconsin Electric Power Company (WEPCO), Atlantic City Electric (ACECO), and Wisconsin Public Service Company (WI PSCo). The contributions of these utilities ranged from $\$ 200,000$ to $\$ 6.6$ million. The three utilities with cash rebates to consumers-LilCo, SMUD, and SCE—offered incentives that ranged from $\$ 75$ to $\$ 95$.
} 


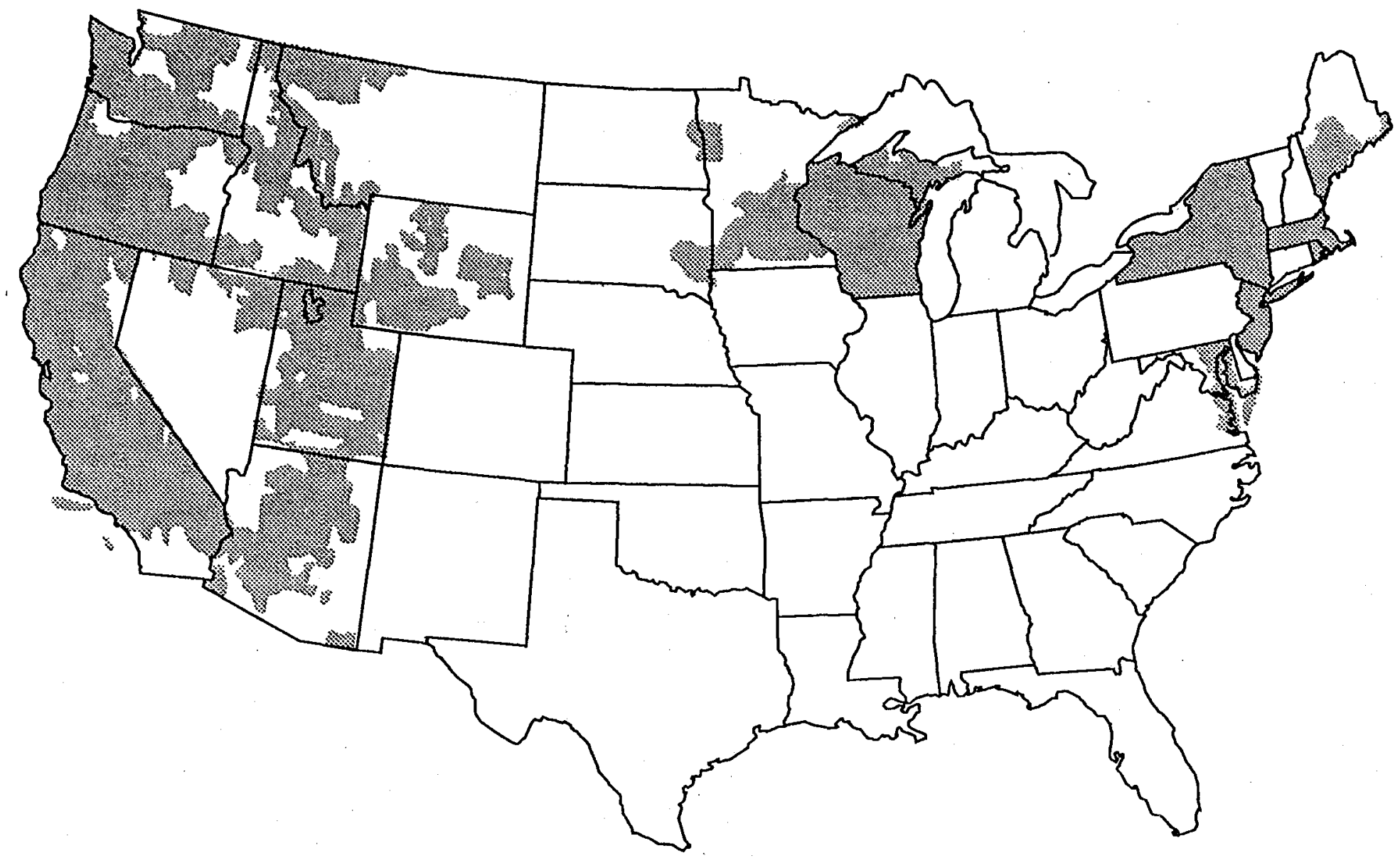

Source: Whirlpool Home Appliances.

Figure 6. Geographic distribution of SERP'M, Inc. utility service territories 
service territory (Farhang cited in Eckert 1995g, p. 1). Most utilities are using bill stuffers or other marketing materials to promote the program.

In 1995, Whirlpool will introduce models that have vacuum panel insulation and are $40 \%$ more efficient than the 1993 standards require (Feist et al. 1994, p. 3.70; Wrigley 1993, p. 3); ${ }^{32}$ these models even exceed the proposed 1998 standards.

\section{Interim Program Results}

Preliminary findings show that the SERPTM, Inc. Program is generating positive results. The program is stimulating the refrigerator industry, eliciting positive consumer response, and fostering unprecedented cooperation among industry, government, and environmental and consumer groups. Indeed, an unanticipated outcome of the SERP process has been the collaboration between industry, environmental and consumer interests, and government in developing proposed 1998 federal efficiency standards for R/Fs (Pollack cited in Eckert 1995h, p. 1; Electricity Daily 1994a, p. 3). The SERP development and implementation process encouraged parties with diverse, and sometimes conflicting, interests to reach agreement. This required fostering communication, cooperation, and long-term planning not normally found among utilities, industry, government, and environmental and consumer groups. In addition, the SERPTM Program required that Whirlpool begin to see SERP ${ }^{\mathrm{TM}}$, Inc., utilities, and environmental and consumer groups as its customers.

The SERPTM, Inc. solicitation generated responses from 14 manufacturers and atracted attention nationwide (see Figure 7). ${ }^{33}$ Although Whirlpool won the bid, participating manufacturers such as Frigidaire, GE, and Amana are using information gleaned from the competition to develop super-efficient models of their own (Farhang cited in Eckert 1994a, p. 3). Appliance industry executives and analysts noted that refrigerator manufacturers could be expected to advertise and promote the energy efficiency and environmental "friendliness" of their products beginning in late 1994 (HFD—Retailing Home Furnishings, January 31, 1994, p. 96; HFD—Retailing Home Furnishings, January 17, 1994; Wrigley 1993, p. 6; HFD—Retailing Home Furnishings, May 31, 1993, p. 140).

Beginning in 1995, Whirlpool will market super-efficient units outside SERPTM, Inc. utility service territories under the banner of "EnergyWise" (Feist et al. 1994, p. 3.69; Anderson cited in Farhar 1994, p. 4; Farhang cited in Eckert 1994a, p. 3). ${ }^{34}$

Whirlpool and SERPTM, Inc. are contemplating an appropriate response should demand for SERPTM R/Fs exceed guaranteed supplies before the program ends. Consumer response to the SERPTM, Inc. units has been overwhelmingly positive. In 1993 alone, Whirlpool received four million inquiries about the SERPTM, Inc. R/Fs. Many consumers in nonparticipating utility service territories were also interested in purchasing the super-efficient units (Anderson cited in Farhar 1994, p. 4; Farhang cited in Eckert 1994a, p. 2-3; Appliance Manufacturer 1994, p. 20). Whirlpool is meeting its sales schedule, but the prospect of insufficient supply is affecting program marketing in some areas. Some utilities are reluctant to give

${ }^{32}$ Whirlpool is incorporating Owens Corning AURATM vacuum panels in both its SERPTM and EnergyWise lines of R/Fs. The panels consist of hermetically sealed, stainless-steel skins surrounding a layer of high-density, rigid fiberglass (Global Environmental Change Report 1995, p. 7).

${ }^{33}$ Approximately 650 U.S. newspapers covered the SERP competition (Anderson cited in Farhar 1994, p. 4).

${ }^{34}$ Whirlpool is marketing $25-\mathrm{ft}^{3}$ and $27-\mathrm{ft}^{3}$ EnergyWise models, which are approximately $38 \%$ more efficient than 1993 federal energy standards (Shaffer cited in Eckert 1995d). 
COYEE STORY

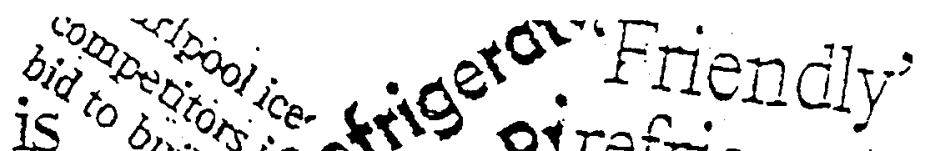

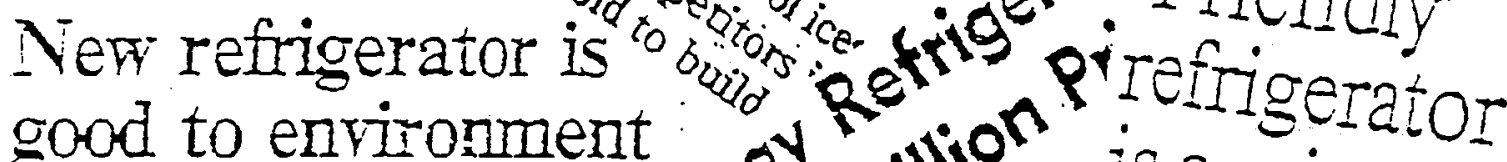
good to environment

\section{Corciand $=0: 3$}

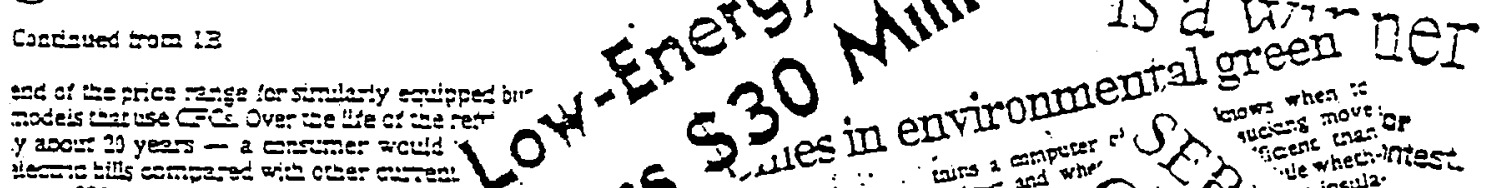
int

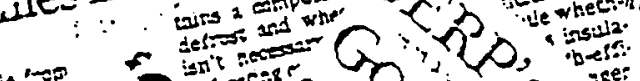
it

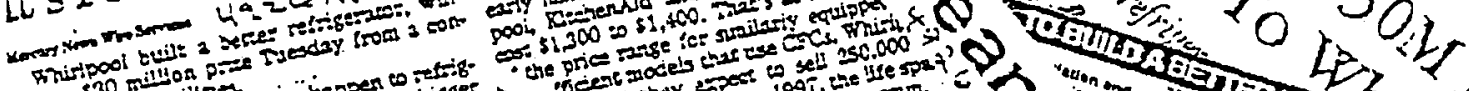

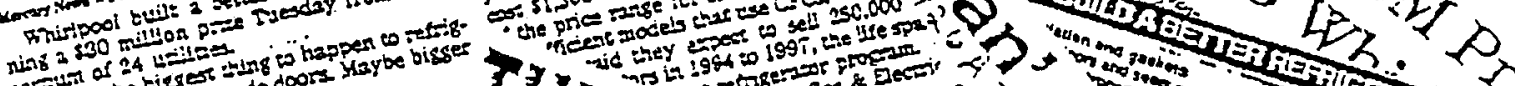
on ris

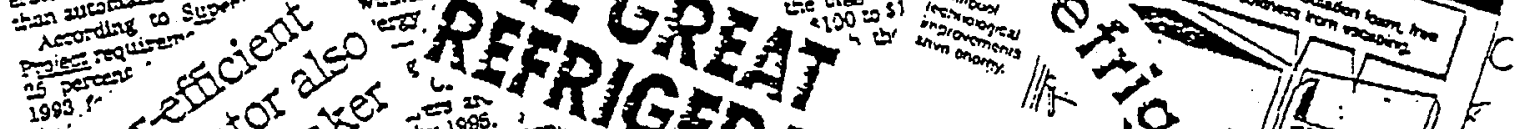

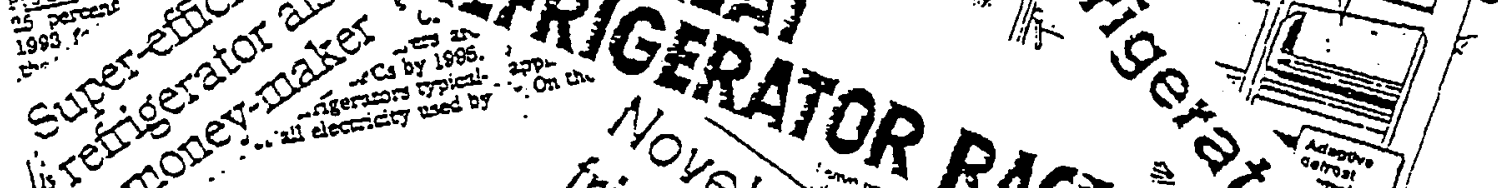
lis $500 \%$.

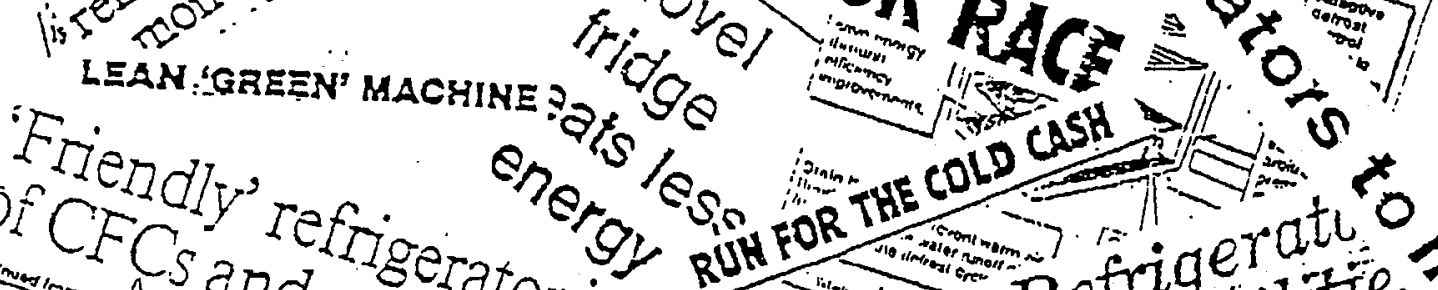

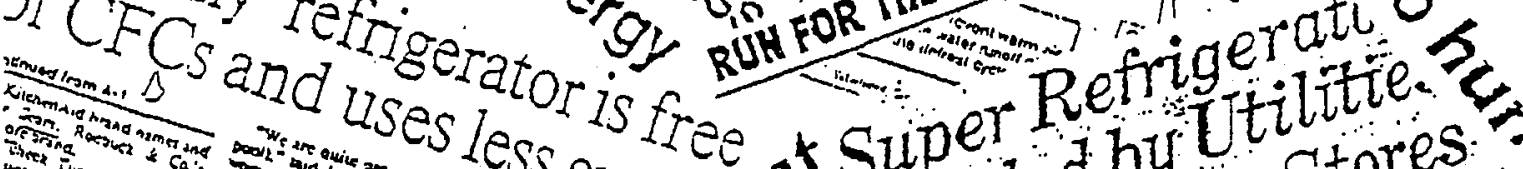

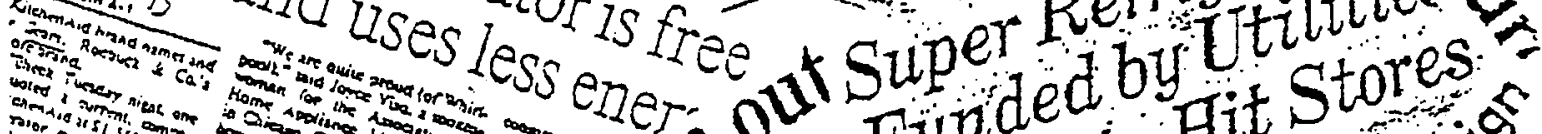

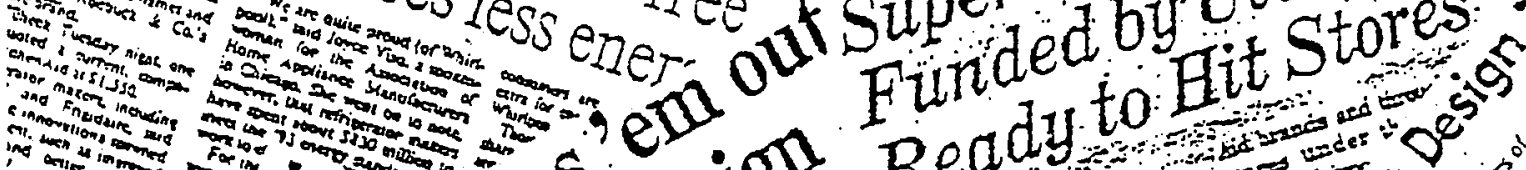

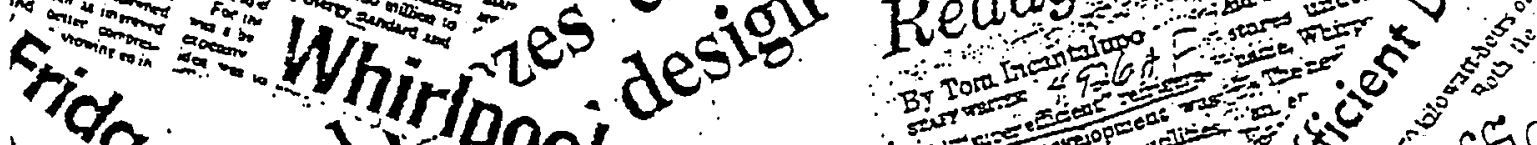

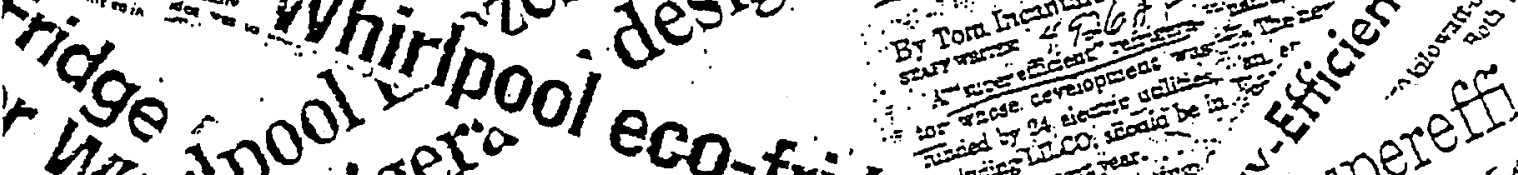

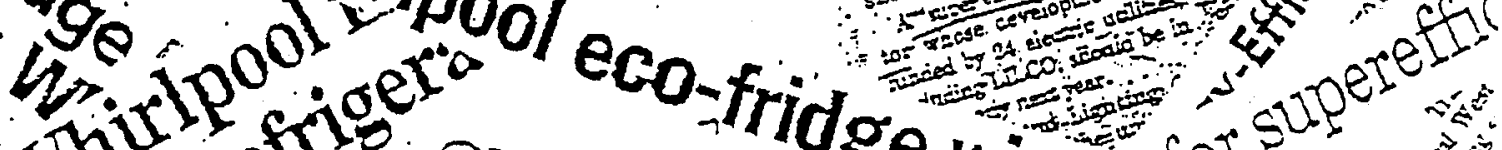

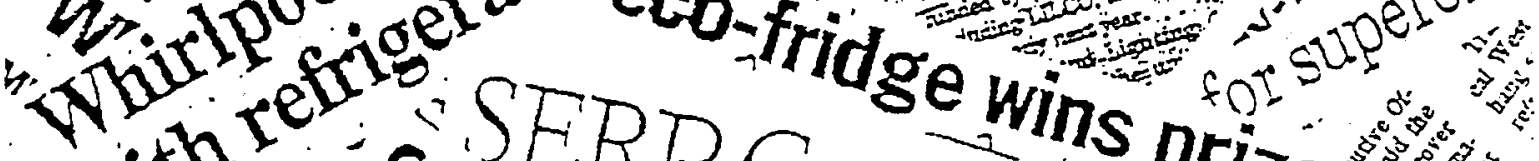

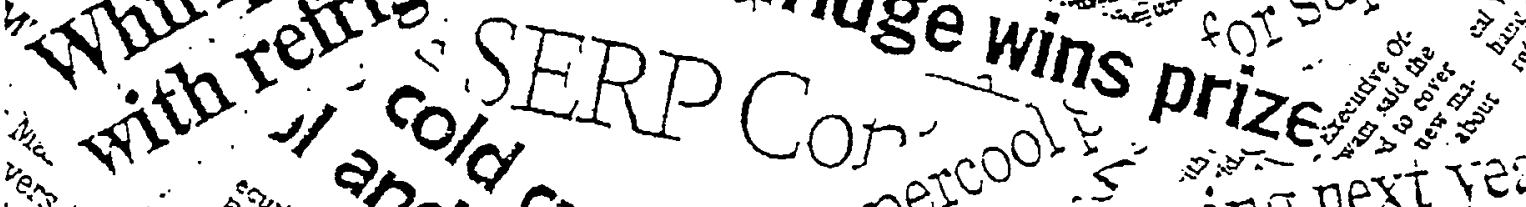

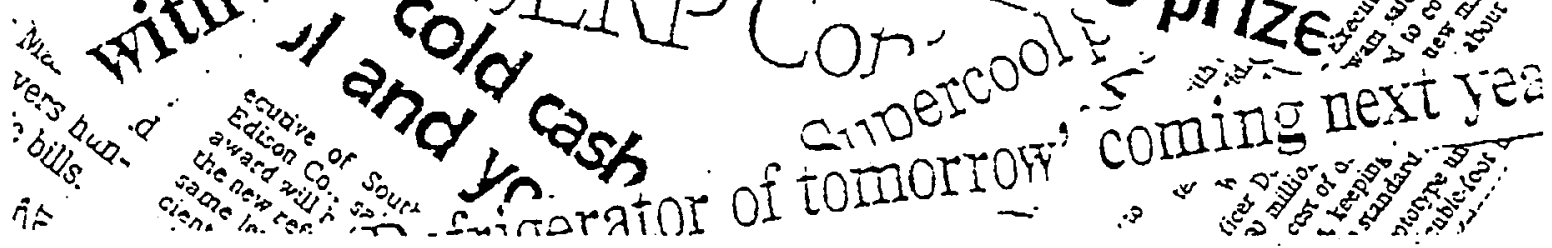

Figure 7. Examples of newspaper headlines on the SERP' ${ }^{\mathrm{TM}}$, Inc., competition 
the program full market exposure and thus risk being unable to respond to customer demand. One utility is containing demand by limiting program visibility to certain markets in its service territories. Distributors could potentially become less willing to market SERPTM, Inc. models should they become difficult to obtain. Whirlpool produces hundreds of models of marketable refrigerators, of which the SERPTM, Inc. model is only one (Farhang cited in Eckert 1994a, p. 2).

\section{Lessons Learned}

Members of SERP ${ }^{\mathrm{TM}}$, Inc., reflecting on their experience with the Golden Carrot program during the past three years, outlined six lessons learned from the process that could be applied to market-pull programs (Feist et al. 1994, pp. 3.73-3.74):

1. Form a coalition. Key stakeholders, including utilities, federal and state agencies, and environmental groups, collaborated to define SERPTM, Inc. Program objectives and format. Manufacturer input, garnered through SERPTM, Inc.'s RFP and contract negotiation process, ensured that program objectives adequately responded to the realities of the market. The collaborative process fostered greater cooperation among the parties involved and increased each party's desire to have the program succeed. ${ }^{35}$

2. $\ddot{Y}$ Establish an independent program structure. Participating utilities established a nonprofit corporation, SERPTM, Inc., to serve as the fiscal and administrative body for the Golden Carrot refrigerator program. The national organization has its own rules of governance, provides program accountability, and sets the Golden Carrot effort apart from other utility DSM programs.

3. Ÿ Use market forces. To be successful, a market-pull program must ultimately involve manufacturers and others in the marketplace. SERPTM, Inc. developed program criteria and objectives but relied on manufacturer input to design a program that would meet SERP ${ }^{\mathrm{TM}}$, Inc. objectives and be successful in the marketplace.

4. $\ddot{Y}$ Address antitrust issues. Antitrust laws limit the collective participation by manufacturers in RFP development. The appearance of an agreement between a manufacturer and the offerer of an RFP that could affect the access of competitors to the bid, had to be avoided. SERPTM, Inc. established guidelines to address antitrust issues. A lawyer provided counsel to SERPTM, Inc. throughout the program development phase, and the SERPTM, Inc. board of directors established policies early on to prevent anticompetitive conduct by participating utilities and manufacturers. In addition, SERPTM, Inc. obtained a Business Review Clearance from the Antirust Division of the Department of Justice.

5. $\ddot{Y}$ Foster competition through the RFP solicitation process. The RFP process produces a competitive environment in which to elicit development of manufacturers' advanced technologies. To ensure manufacturers' full participation, SERP ${ }^{\mathrm{TM}}$, Inc. established saf eguards to ensure a fair bidding process and to protect confidential information. These measures included restricting manufacturers from sitting on the SERPTM, Inc. board of directors, attending Advisory Committee sessions, and

\footnotetext{
${ }^{35}$ In August 1994, ACEEE awarded the 1993 Champion of Energy Efficiency Award to six individuals responsible for developing and implementing the SERPTM, Inc. Program. The ACEEE award pays wibute to the "pioneering" effort of the founders of the Golden Carrot prototype, who worked to invent a whole new category of program (Geller cited in Farhar 1994, p. 1). In the short span of 31/2 years, the program spurred the design, development, and commercialization of a super-efficient refrigerator. The six individuals honored were David Goldstein of the NRDC, Gary Fernstrom and Paul Brodie of PG\&E, Mike L'Ecuyer of the EPA, Ray Farhang of SCE, and Vince Anderson, Director of Environmental Programs at the Whirlpool Corporation.
} 
participating in initial SERPTM, Inc. Program design, and developing procedures to protect proprietary information disclosed by manufacturers.

The winner-take-all approach adopted by SERPTM, Inc. is one of many possible strategies that could be used to provide incentives to manufacturers. The CEE is testing alternative market-pull strategies that combine the guarantee of a large market and uniform utility product efficiency levels with consumer education, product marketing, and rebate programs sponsored by participating utilities. ${ }^{36}$ Program variations on SERPTM, Inc.'s bid pool design have not been tested.

6. $̈$ Establish measurement and evaluation protocols. Providing measurable outcomes allows SERPTM, Inc. to evaluate whether program goals have been achieved and enables participating utilities to demonstrate to regulators that the program is benefitting the customers served. By collecting tracking data, SERPTM, Inc. can "identify regional markets, identify consumer behavior in those markets, and identify sales in a particular time frame in which to study market behavior." (Feist et al., 1994, p. 3.74)

${ }^{36}$ For a discussion of other Golden Carrot strategies being tested, see Section 4, which outlines three CEE initiatives. 


\section{Section 4. CEE Golden Carrot Initiatives}

The Consortium for Energy Efficiency (CEE) centrally coordinates program design and development and facilitates program implementation of high-efficiency technologies. For each program sponsored, the Consortium coordinates utility participation nationwide, builds markets large enough to at ract the attention of manufacturers, and facilitates the interchange of information between manufacturers and utilities. CEE-built markets encompass an estimated $15 \%$ to $20 \%$ of the U.S. market (Alexander cited in Farhar 1994, p. 5). Market-pull strategies being considered by CEE include the "contest approach" (for example, the SERPTM, Inc. Program), labeling, education and marketing, rebates or manufacturer subsidies, and the use of state and federal procurements (Alexander cited in Farhar 1994, p. 6).

CEE's first three Golden Carrot initiatives are using the incentive of a large market, consistency in product efficiency levels adopted by participating utilities, and concomitant utility incentive programs to atract manufacturers (Alexander cited in Farhar 1994, p. 5; Consortium for Energy Efficiency 1994a, p. 1). The following are descriptions of CEE's three programs-High-Efficiency Air Conditioners, Residential Clothes Washers, and Split-System Air Conditioners and Heat Pumps.

- High-Efficiency Commercial Air Conditioners (HECAC): By establishing uniform energy efficiency specifications, this initiative aims to encourage the development and availability of high-efficiency airconditioning units that can be promoted through utility rebate programs. Utilities, environmental and public interest groups, and government agencies designed the HECAC program with input from product manufacturers. Utilities participating in the program are adopting energy efficiency specifications for commercial air conditioners recommended by CEE. ${ }^{37}$ These specifications fall into two tiers. Tier 1 identifies energy efficiency specifications for products that are currently-or will soon be - on the market. Second-tier specifications, which are more stringent, are intended to encourage manufacturers to develop super-efficient models. ${ }^{38}$ Utility support of Tier 2 specifications demonstrates to manufacturers that there would be market support for the development and production of even more advanced units. CEE is leaving incentive program design to the discretion of individual utilities (Consortium for Energy Efficiency 1994b, pp. 1-2; Consortium for Energy Efficiency 1994c, pp. 1-8). The time frame for this program is 1994-1996 for Tier 1 equipment and 1996-1998 for Tier 2 models.

- Residential Clothes Washers: This initiative advances energy- and water-saving clothes washers (e.g., horizontal-axis and high-spin-speed washers) by encouraging participating utilities to adopt recommended energy and water efficiency eligibility thresholds for residential clothes washers. CEE is encouraging utilities to develop incentive programs that support these specifications. The Consortium suggests that electric, gas, water, and sewer utilities share the cost of the incentives. Utilities could jointly offer incentive programs, with each utility paying for the savings of its own resource. CEE expects the program to run from 1994 through 1996 (Consortium for Energy Efficiency 1994a, p. 1; Consortium for Energy Efficiency 1994d, pp. 1-9).

- Split-System Air Conditioners and Heat Pumps: CEE recommends "efficiency thresholds"—ranging from 0 to Advanced (level 5) - for cooling and heating performance of split-system residential air

${ }^{37}$ HECAC guidelines state that CEE energy efficiency specifications are "recommended eligibility levels for incentive programs but are not exclusive and are not compulsory." Participating utilities are free to complement CEE specifications with incentive programs for products meeting both lower and higher efficiency levels (Consortium for Energy Efficiency 1994b, p. 1).

${ }^{38}$ According to CEE, $10 \%-15 \%$ of air conditioners certified by the American Refrigeration Institute meet Tier 1 efficiency levels (Consortium for Energy Efficiency 1994c, p. 1). 
conditioners and heat pumps, as does the HECAC program. To participate in the program, utilities must adopt Tier 2 and Tier 3 efficiency specifications and agree to provide incentives for units meeting those levels. CEE encourages utilities to adopt higher product efficiency levels and to pro rate rebate amounts according to the level of efficiency. In addition, the Consortium is recommending that utilities add an "installation component" to their incentive programs. This added feature would make rebates contingent on the correct installation of heating and cooling systems specified in CEE guidelines. CEE urges participating utilities to adopt Tier 1, 2, 3, and advanced specifications in their 1995 programs, and to continue offering incentives through 1996 for Tier 1 and through 1998 for higher tiers (Consortium for Energy Efficiency 1994e, pp. 1-12).

CEE subcommittees are considering or developing Golden Carrot initiatives for the following end-use technologies:

- Residential and small commercial lighting

- Industrial motor systems

- Gas technologies (for example, a gas air conditioner/heat pump initiative)

- Residential air-conditioning

- Residential heat pump water heaters

- Commercial chiller systems

- Compact fluorescent fixtures

- Advanced lighting technology challenge

- Vending machines/beverage merchandisers

- Residential refrigerators (in addition to the SERPTM, Inc. Program)

- Water conservation technologies (e.g., showerheads) (Consortium for Energy Efficiency 1994a, pp. 1-2).

In addition, CEE has convened subcommittees to explore coordinating CEE programs with market-pull programs in other countries, to research energy efficiency-related data bases, and to develop appropriate measurement and evaluation protocols for determining market ransformation effects (Consortium for Energy Efficiency 1994a, p. 2). 


\section{Section 5. Legislative and Federal Support for Golden Carrot Programs}

The SERPTM, Inc. Program has influenced subsequent federal legislation and policy initiatives. EPAct calls for a report to Congress on candidate technologies that might benefit from market-pull programs. The Clinton Administration's CCAP of 1993 promotes the development of public/private partnerships to reduce greenhouse gas emissions through energy efficiency programs and other initiatives. Two of the 44 "actions" listed in the plan encourage Golden Carrot efforts.

\section{Report to Congress on Candidate Technologies for Development and Commercialization Programs and Proposed Action Plan}

EPAct (Title I, Subtitle C, Section 127) required that the Secretary of Energy, in consultation with the Administrator of the EPA, utilities, and appliance manufacturers, prepare a report by 1994 on the potential for developing and commercializing appliances that are significantly more efficient than required by federal and state standards. The report must identify candidate high-efficiency appliances that (1) have the potential to be made substantially more energy efficient; (2) promise to be cost effective for consumers; (3) have the support of utilities willing to promote the commercialization of the appliances, and; (4) are unlikely to be developed and commercialized by manufacturers, or would be developed and commercialized at an accelerated pace if manufacturers received support.

The report must also include proposed actions that could be taken by DOE and EPA to coordinate and assist utilities and manufacturers in developing and commercializing highly efficient appliances. In addition, the report must cover suggested methods for using federal procurement to provide a market for these super-efficient appliances, and recommend funding levels needed to develop and implement a federal program for developing and commercializing super-efficient end-use technologies. The report, entitled Partnerships for Technology Introduction-Putting the Technologies of Tomorrow into the Marketplace Today, was published in April 1995.

\section{CCAP Action \#6: Form "Golden Carrot" Market-Pull Partnerships}

CCAP Action \#6 calls for the formation of "Golden Carrot" market-pull partnerships (Clinton and Gore 1993 [Action Description p. 7]). Integral to this effort to commercialize super-efficient technologies are partnerships among EPA, DOE, and "key market players" such as utilities, manufacturers, dealers, environmental groups, and public agencies. CEE is to design and implement programs. Action \#6 directs DOE to use the study on candidate technologies for market-pull programs (EPAct, Section 127) to update and expand the list of technologies proposed for Golden Carrot initiatives. In addition, DOE is to assist with program design and marketing. The Clinton Administration estimates that Action \#6, together with the promulgation of more stringent residential appliance standards, will stimulate $\$ 19.5$ billion in privatesector investments for the period of 1994 to 2000, will yield $\$ 9.4$ billion in energy savings, and will reduce greenhouse gases from projected 2000 levels by 11.8 million metric tons (MMT) of carbon equivalent. In addition, the Administration projects that the investment will continue to pay off over the next decade, for added savings of about $\$ 40.7$ billion (Clinton and Gore 1993 [Action Description p. 7]).

\section{CCAP Action \#13: Establish Golden Carrot Programs for Industrial Air Compressors, Pumps, Fans, and Drives}

CCAP Action \#13 encourages the creation of Golden Carrot programs for industrial air compressors, pumps, fans, drives, and other industrial process equipment. Target industries include the pulp and paper, 
textile, chemical, petrochemical, and food-processing industries, which use more than $50 \%$ of the process energy consumed by this sector (Clinton and Gore 1993 [Action Descriptions p. 14]).

Action \#13 outlines the following four activities that are designed to accelerate the commercialization of high-efficiency models for these four end-use technologies:

- A DOE-sponsored study that quantifies potential efficiency gains from advanced, high-efficiency air compressors, pumps, and fans, and identifies other types of process equipment with the potential for cost-effective efficiency gains (EPAct, Section 127)

- A joint effort among utilities, industrial firms, the government, energy users, and nonprofit organizations to establish common utility specifications and financial incentives to promote the commercialization of advanced, high-efficiency equipment. This effort will ensure that utilities develop uniform specifications for high-efficiency equipment purchases and provide monetary incentives for their use.

- A utility-led effori to develop contests similar to the SERPTM, Inc. Program for refrigerators

- A private-sector, pooled purchasing project to enable industrial energy users to jointly make large purchases of high-efficiency industrial equipment at a lower price than individual purchasers.

The Clinton Administration calculates that estimated energy savings from this Action would be $\$ 1.3$ billion through 2000. Private-sector investment would approach $\$ 600$ million, and emissions would be reduced by 2.9 MMT from projected 2000 levels. Over the next decade, projected additional savings would amount to about $\$ 7.8$ billion (Clinton and Gore 1993 [Action Descriptions p. 14]).

\section{DOE Partnerships for Technology Introduction}

DOE's FY 1996 budget requests funds to implement CCAP Action \#6 beginning in FY 1995 . The Partnerships for Technology Introduction program will initiate a government-industry collaborative program to accelerate the introduction and widespread use of high-efficiency heating and cooling technologies. In cooperation with EPA, DOE will design and implement technology introduction partnerships consisting of utilities, state and local governments, and manufacturers. These partnerships will target specific technologies and market segments, leveraging federal funds with coordinated and expanded utility incentives and group purchasing strategies. Candidate technologies for accelerated development include high-efficiency electric heat pumps and air conditioners, high-efficiency packaged rooftop heating, ventilating, and air-conditioning (HVAC), gas-fired heat pumps, advanced thermal distribution systems, and non-CFC high-efficiency chillers.

Initially, the program will build partnerships with national account companies that own or control large inventories of buildings nationally and make central energy-equipment decisions. In subsequent years, DOE will cultivate partnerships with retailers of HVAC equipment and energy service companies, and will work with partners to aggregate purchasing power to stimulate the market for high-efficiency HVAC products. In addition, the Department will continue to target technologies that can be exported to international markets. Requested FY 1996 funding for this effort is $\$ 4.480$ million for FY 1995 and \$4.962 million for FY 1996. 


\section{DOE Motor Challenge Program with Market Transformation Strategies}

The goal of the Motor Challenge Program, which integrates CCAP Actions \#12 and \#13, is to increase market peneration of energy-efficient electric motor systems (EMS). FY 1994 activities in support of this goal included showcase demonstrations of electric motor drive systems, the development of an EMS data base, voluntary industrial deployment, and an information dissemination and resource center network. In FY 1995 and FY 1996, the program will expand the showcase demonstrations to include other industries and uses of high-efficiency motors and adjustable speed drives. In addition, the program will foster partnership activities, deployment through regional collaboratives and education and training workshops, and market transformation strategies. The FY 1996 budget request includes $\$ 3$ million for FY 1995 Motor Challenge activities and \$5.648 million for FY 1996 program support.

The market ransformation strategies component of the Motor Challenge Program implements CCAP Action \#13. In FY 1995, this program will develop the last part of the high-efficiency motor, adjustablespeed drive equipment system; will identify candidate equipment, technologies, and services; and establish voluntary test procedures for pumps, fans, and compressors. In FY 1996, DOE will implement programs to elicit industry demand for industrial pump, fan, and compressor systems. Market transformation strategies will include a series of coordinated actions such as working with industry to develop voluntary test procedures, protocols, performance guidelines, and raining and certification, as well as support to private/public purchasing and procurement initiatives. DOE will collaborate with CEE, ACEEE, utilities, and end-user companies to implement this part of the Motor Challenge Program. The requested Motor Challenge budgets for FY 1995 and FY 1996 are \$1.5 million and \$2.3 million, respectively. 


\section{Section 6. Conclusions}

This case study of the SERPTM, Inc. Program describes a model for using market forces to hasten the development and commercialization of super-efficient technologies. As the first Golden Carrot program to be implemented in the United States, SERP - and subsequent Golden Carrot programs spawned by $\mathrm{CEE}$ - will serve as promising examples for future efforts.

The SERPTM, Inc. model distinguishes itself in several ways. First, participating utilities formed a separate administrative and fiduciary body to oversee the development and implementation of SERP. This central body offers administrative efficiency advantages over short-term DSM programs by reducing overhead and management costs through economies of scale. Second, program designers linked a long-term DSM program format with the development and commercialization of new products. This required utilities to invest in long-term efficiency gains while providing manufacturers with the incentive and time needed to solve both the CFC phase-out and the SERP energy efficiency challenge. Third, SERPTM, Inc. elected to use an RFP bid process to secure utility and manufacturer participation, and to create a competitive environment that would challenge manufacturers to exercise their R\&D capabilities. Fourth, the use of a legally binding contract obligated the winning manufacturer to adhere to the terms outlined in the bid and committed SERPTM, Inc. to disburse the funds promised. Subsequent Golden Carrot programs have instituted more flexible terms. Finally, SERP virtually eliminates free ridership.

In addition, SERP and other Golden Carrot programs capitalize on the drive of manufacturers to increase market share. The guarantee of an exclusive market and the opportunity to capture a corner of the market with a new and unique product proved to be more atractive to SERP competitors than the financial incentive. This desire for market share motivated R/F manufacturers to compete for SERP ${ }^{\mathrm{TM}}$, Inc.'s $\$ 30$ million bid pool, and ultimately prompted several major R/F manufacturers to produce and market competing super-efficient units. SERP ${ }^{\mathrm{TM}}$, Inc.'s successful incorporation of market forces in its program design has been one of the program's notable characteristics.

Interim program results are promising. The SERPTM, Inc. competition yielded data on the maximum efficiency levels that can be cost effectively attained for R/F technology and resulted in the development of a CFC-free refrigerator with no compromise in product efficiency. The information generated by this competition contributed to DOE's revision of 1993 NAECA standards for R/Fs; proposed 1998 standards will require refrigerators to be $22 \%$ to $30 \%$ more efficient than those available today. ${ }^{39}$ The program is eliciting a positive response from consumers, and SERPTM, Inc. utilities are contemplating what course to take should demand for SERPTM units exceed Whirlpool's guaranteed supply. In addition, Whirlpool and SERPTM, Inc. are debating whether the manufacturer should market the SERPTM R/Fs nationwide before the con ract with SERPTM, Inc. expires. Whether SERP is effecting enduring changes in the market for refrigerators awaits further investigation. The results of forthcoming evaluations of SERP will shed light on the viability of the SERP ${ }^{\mathrm{TM}}$, Inc. model and the long-term impacts of the program.

${ }^{39}$ The proposed 1998 standards require a "typical" refrigerator to consume approximately $550 \mathrm{kWh} /$ year. Parties involved in negotiating the new standards included AHAM, NRDC, ACEEE, the New York State Energy Office, the CEC, PG\&E, and SCE. Most of these stakeholders were involved in developing SERP (Electricity Daily 1994a, p. 1). 


\section{Policy Questions}

The evolution of the Golden Carrot concept has largely been a grassroots effort. CEE is replicating this joint effort, which involves utilities, government, energy efficiency advocates, and industry, in application to other energy efficiency products.

EPAct of 1992 and CCAP of 1993 established federal legislation and encouraged interest in Golden Carrot programs. The direction these programs will take and the roles of policy makers in these programs are evolving. As policy makers explore various options, a number of questions arise.

1. ^Are voluntary Golden Carrot programs more effective in sparking manufacturer creativity and commitment to the production of energy-efficient appliances than mandatory federal appliance standards? Or are both needed?

SERP is a good example of how a Golden Carrot Program can work in tandem with a federal appliance standards program to spark manufacturers to produce more energy-efficient products. Architects of the R/F program factored in several key elements that made this possible: (1) R/F R\&D was sufficiently advanced that, with some effort, it could be incorporated in marketable R/F units; (2) the R/F industry is a mature industry, with the larger manufacturers having R\&D programs and developed links with distributors. For the major competitors in the industry, the SERPTM, Inc. competition offered the lure of a guaranteed market, the challenge of capturing additional market share, promised a competitive edge with a new product, positive national publicity, and a financial incentive; (3) the impending ban on CFCs in manufacturing and the 1993 energy efficiency standards were challenges faced by all R/F manufacturers, and; (4) the program was voluntary.

Golden Carrot programs capitalize on the desire of all manufacturers to increase market share; however, the effectiveness of these programs in stimulating manufacturers to develop products that exceed federal standards depends on the industry and the technology, the program model, and the technological feasibility of further efficiency gains. CEE has just implemented Golden Carrot programs for clothes washers and for commercial air conditioners. Although both programs offer incentives to customers and product manufacturers to encourage graduated improvements in product efficiency levels, both incorporate federal standards, or other efficiency baselines for unregulated appliances, into their program designs. It will be several years before the results of this approach are available.

\section{2.» Is the SERPTM, Inc. model transferable to other technologies?}

The SERPTM, Inc. model has not yet been replicated and may only be appropriate to mature industries in which several major manufacturers dominate the market. Major manufacturers tend to have wellcapitalized R\&D programs, nationwide product distribution networks, and numerous production facilities. All of these were important factors in the SERP model.

The initiatives being implemented or considered by CEE suggest that the Golden Carrot concept can be adapted to other industries. However, not all products lend themselves to the same market-pull strategy. Factors such as whether energy efficiency is perceived as a prominent feature of a product (for example, efficiency is perceived as an important feature of lighting but not necessarily of computers); whether manufacturers have large, small, or nonexistent R\&D programs; or whether the technology is subject to federal regulation, all influence the approach that might best be used (Nadel and Geller 1994, p. 10.189). 
Golden Carrot strategies have been successfully used in other applications. For example, Bonneville Power Administration, regional utilities, state representatives, industry representatives, and others developed and successfully implemented a program to increase the energy efficiency and market penetration of manufactured houses in the Northwest (Lee 1994, p. 77). The adaptability and effectiveness of Golden Carrot incentives in other areas (such as advancing emerging technologies with broad applications or finding alternatives to the use of environmentally degrading substances or practices) have yet to be explored.

\section{What is the appropriate federal role with respect to Golden Carrot programs?}

Federal support for Golden Carrot programs such as SERP has primarily involved technical expertise, staff support, and ancillary financial support. However, direct government subsidy of the cost of a Golden Carrot program such as SERP raises a host of questions regarding the mission of the federal government and the use of federal funds. Concerns raised within DOE include:

- The legality of subsidizing a product manufacturer with federal funds

- The feasibility of using the federal procurement process to provide a market for end-use technologies developed through Golden Carrot programs

- The effectiveness of using federal funds to advance select end-use technologies

- The extent to which a federal agency should share in the patent rights and returns if the agency participates in the development of a new technology and the subsidy of industrial manufacturing economies of scale

- The agency's position on directly or indirectly supporting foreign product design or manufacture, or both, should a foreign product manufacturer win a SERP model competition

- The type of requirements for monitoring and evaluating technologies deployed through market-pull initiatives and the agency's position on specific liabilities of program participants if problems in product performance arise.

4. » What are the implications of electric industry deregulation for market-pull programs such as SERP?

EPAct and subsequent developments opened the way for wholesale and retail transmission of electricity. The impacts of this competitive environment are just beginning to be assessed; some of these assessments bode well for DSM, while others conclude that competition would be less conducive to launching Golden Carrot initiatives such as SERP.

Under one scenario, the generation sector could become separate from the transmission and distribution (T\&D) sector. T\&D companies would continue their traditional utility responsibilities of planning and acquiring supplies, but from an unregulated, competitive generating sector. Limited transmission capability arising from constraints such as voltage-related factors and thermal limits could encourage T\&D companies to control demand by continuing DSM programs. Just what form deregulation will take is unknown, as are the repercussions for programs such as SERP.

Should competitive wholesale and retail market conditions prevail, DSM programs may not fare as well. First, the avoided cost of utilities is likely to be lower. This will likely reduce the cost- 
effectiveness of DSM programs, including candidate Golden Carrot programs. Second, utilities with increased demand would be able to meet their energy needs by purchasing power from other utilities on the wholesale market, thus eliminating the original incentive to invest in a long-term DSM program. Third, without captive customers, utilities could no longer offer a guaranteed market to manufacturers, nor be assured that the cost of a long-term investment would be recouped. Finally, in a competitive environment, utilities have little incentive to collaborate with competitors.

CEE is currently exploring program design options adapted to the changing market conditions in the electric utility industry (for example, those involving large industrial customers, energy service, and/or distribution companies).

\section{Future Needs}

Whether the SERPTM, Inc. Program will effect a long-lasting shift in the way society views energy production and consumption is still unknown. Interim evaluations of program process and results are forthcoming. Preliminary findings on the SERPTM, Inc. Program reveal that competing R/F manufacturers are producing super-efficient models of their own and that the SERPTM units are eliciting a positive response from consumers. However, questions still to be answered include whether the market share for super-efficient $\mathrm{R} / \mathrm{Fs}$ will expand or whether more consumers will place a premium on energy-efficient and environmentally "friendly" products.

Whirlpool now faces the challenge of cost effectively producing the SERPTM units. The company must either attain economies of scale or raise the price of its R/Fs. In addition, data are needed on SERPTM regional markets; consumer behavior; changes in demand over time; the frequency of sales; the frequency of cross-border sales; the environmental, energy, and dollar savings of SERPTM units purchased; and changes in the supply of super-efficient R/Fs, particularly as other manufacturers begin to promote competing models and as Whirlpool struggles with demand for the SERPTM product. Evaluation of the answers to these and other questions will enable program managers to draw conclusions about the longterm prospects of the SERP Program.

In the meantime, the incorporation of CEE and SERPTM, Inc. provides an institutional framework for further developing and implementing Golden Carrot programs. Both EPAct and CCAP established starting points for defining the role of Golden Carrot programs in federal policy. Alternative program formats and different incentives may need to be tested as the structure of the electricity industry changes and as the results of these programs are evaluated. If market-pull programs such as SERP continue to be successful and can be adapted to the long-term challenges of the market, then it will be possible to enjoy long-lasting energy efficiency and environmental benefits. 


\section{Bibliography}

American Council for an Energy-Efficient Economy. (October 1991). The Golden Carrot News. Washington, D.C.: American Council for an Energy-Efficient Economy. No. 3.

Appliance. (October 1993). "A Furiously Fast Fridge." p. 32.

Appliance Manufacturer. (May 1994). "Super Efficient Refrigerator Program: Developing a Winner." p. 20.

Association of DSM Professionals. (Winter 1991). "“Golden Carrot' Seen as an Appetizing Idea." Strategies 7, Vol. 2.

Atlanta Constitution. (June 30, 1993). "Whirlpool wins super-efficient refrigerator contest."

Benson, D.K. and Potter, T. (1992). "The Effect of New Priorities and New Materials on Residential Refrigerator Design." ACEEE 1994 Summer Study on Energy Efficiency in Buildings Proceedings, Panel 2, Residertial Technologies: Design and Operation. Washington, D.C. Berkeley, CA: American Council for an Energy Efficient Economy, pp. 2.13-2.21.

Bukro, C. (June 30, 1993). "Refrigerator Design Cools Use of Energy." The Chicago Tribune.

Business Communications Company. (July 1993). "The Changing Refrigeration Industry Trends: SuperEfficient Refrigerator Program." Business Communications Company, Inc.

Clinton, W.; Gore, A. (October 1993). The Climate Change Action Plan. Washington, D.C.: Government Printing Office.

Consortium for Energy Efficiency. (April 1994a). "Consortium for Energy Efficiency Projects (as of April 1994)."

. (1994b). "The Consortium for Energy Efficiency's High Efficiency Commercial Air Conditioning (HECAC) Initiative."

. (January 1994c). "The Consortium for Energy Efficiency High Efficiency Commercial Air Conditioning (HECAC) Initiative-Final Program Description."

. (August 15, 1994d). "Program Outline for Multi-Utility Clothes Washer Incentive Eligibility Standards."

. (June 16, 1994e). "Consortium for Energy Efficiency Residential Central Air Conditioner and Heat Pump Program-Final Program Description."

(September 1991f). "Executive Committee Meeting" (draft minutes), August 6, 1991, Napa, CA: Consortium for Energy Efficiency.

Culviner, Prall. (February 6, 1995). "DOE Gives $\$ 800,000$ to Consortium to Promote Energy Efficient Tech." The Energy Report, p. 96. 
Demand-Side Report (1994). "Socal Ed Refrigerator Recycling Effort Saved 30 GWh; 33 MW Peak Cut Expected." Demand-Side Report, August 18, pp. 4-5.

. (February 2, 1995). "BGE Faces Royalties on Appliance Unit as Dealers Charge Unfair Rate Subsidies." Demand-Side Report, p. 1.

Design News. (April 15, 1994). "Appliance Makers Turning to Custom Materials." Design News, p. 23.

DOE. (August 1979). Office of Buildings and Community Systems Multi-Year Plan (Draft). . (1995). DOE FY 1996 Congressional Budget Request, Energy Conservation,

Buildings Sector. Washington, D.C.: DOE, pp. 243-245, 252-254, 285-286, and 351-352.

. (no date [a]). Building Energy Research and Development Input to the Conservation FY 1986 Program Document. Washington, D.C.: DOE.

DOE/EE. (November 1993). Technical Support Document: Energy Efficiency Standards for Consumer Products, Room Air Conditioners, Water Heaters, Direct Heating Equipment, Mobile Home Furnaces, Kitchen Range and Ovens, Pool Heaters, Fluorescent Lamp Ballasts, and Television Sets, Vol. 1: Methodology. DOE/EE-0009. Washington, D.C.: DOE.

DOE/EIA. (January 1994a). Electric Power Annual 1992. DOE/EIA 0348 (92). Washington, D.C.: Government Printing Office.

. (April 1994b). Monthly Energy Review. DOE/EIA 0035 (94/04). Washington, D.C.: Government Printing Office.

. (November 1994c). Emissions of Greenhouse Gases in the United States, 1987-1992. DOE/EIA-0573. Washington, D.C.: Government Printing Office.

. (February 1993). Household Energy Consumption and Expenditures 1990. DOE/EIA 0321 (90). Washington, D.C.: Government Printing Office.

DOE/OBCS. (August 1979). Office of Buildings and Community Systems Multi-Year Plan (Draft).

April 4. . (no date [a]). Building and Community Systems Multi-Year Plan, 1988-1992(?). (Draft).

(April 18, 1989). Office of Buildings and Community Systems Multi-Year Plan, FY 19911994. ("Alternative Version"). Washington, D.C.: DOE.

DOE/OBT. (1994). CORE Databook. Washington, D.C.: DOE. June 24. Eckert, Jan B. 1994a. Personal communication with Ray Farhang on August 24, 1994. (draft notes), pp. 1-6.

DOE Office of Conservation. (September 1987). Energy Conservation Multi-Year Plan FY 1989-1993. Washington, D.C.: DOE.

Washington, D.C.: DOE. (August 1988). Energy Conservation Multi-Year Plan, 1990-1994. 
Chapters 48. Washington, D.C.: DOE.

(August 16, 1989). Energy Conservation Multi-Year Plan, 1991-1995,

Chapter 2.0, "Overview." (Third Draft).

DOE Office of Conservation and Renewable Energy. (November 17, 1989). "Energy Conservation

Program for Consumer Products: Energy Conservation Standards for Two Types of Consumer

Products; Final Rule and Determinations and Analyses of Competitive Impacts." Federal Register;

Vol. 54, No. 221. pp. 47,916-47,945.

Eckert, J. (August 24, 1994a). Personal communication with Ray Farhang (Draft Notes).

. (September 22, 1994b). Personal communication with Ray Farhang (Draft Notes), pp. 1-9.

_. (September 30, 1994c). Personal communication with Thomas Potter (Draft Notes),

pp. $1-5$.

. (January 1995a). Personal communication with Ed Pollack (Draft Notes), pp. 1-3.

. (February 15, 1995b). Personal communication with Ed Pollack (Draft Notes), p. 1.

- (January 25, 1995c). Personal communication with Linda Sandahl. Pacific Northwest Laboratory, Richland, Washington, (Draft Notes), p. 1.

. (February 17, 1995d). Personal communication with Peter Shaffer, Technical Consultant, Whirlpool Consumer Assistance Center, quoting from the "Engineering Specifications Database" produced by Whirlpool Corporation Research \& Engineering Refrigeration Products (Draft Notes), p. 1.

Notes), pp. 1-2.

(March 10, 1995e). Personal communication with David Goldstein (Draft

. (March 10, 1995f). Personal communication with Isaac Turiel (Draft Notes), p. 1.

. (March 17, 1995g). Personal communication with Ray Farhang (Draft Notes), p. 1.

. (March 31, 1995h). Personal communication with Ed Pollack (Draft Notes), p. 1.

. (June 1, 1995i). Personal communication with Kelly Morairty (Draft Notes).

Electric Power Research Institute. (29 June 1993). "EPRI Testing of Super Efficient Refrigerators Confirms Significant Advance in Technology" (news release). Palo Alto, California: Electric Power Research Institute.

Electricity Daily. (October 19, 1994a). "Greens, Industry Agree on New Refrigerator Standards." Electricity Daily, Vol. 3, No. 76, p. 1.

Vol. 3, No. 40, p. 1.

. (August 16, 1994b). "EPRI, Maytag Develop Existing Technology." Electricity Daily; 
. (February 24, 1994c). "O’Leary: Let the Good Fridge Roll." Electricity Daily, Vol. 2, No. 37, p. 3.

. (February 3, 1995). "CEE Gets Golden Carrot Grant." Electricity Daily, Vol. 4, No. 23,

p. 3.

Fang, J.M.; Balistocky, S.; Schaefler, A.M. (December 1982). Issues in Federal Preemption of State Appliance Energy Efficiency Regulations. PNL-4549. Richland, WA: Pacific Northwest Laboratory.

Fang, J.M.; Tawil, J. (December 1980). Analysis of Alternative Strategies for Energy Conservation in New Buildings. PNL-3309/UC-95d. Richland, WA: Pacific Northwest Laboratory.

Farhar, B. (August 31, 1994). "1993 ACEEE Champion of Energy Efficiency Award Ceremony at ACEEE 1994 Summer Study on Building Energy Efficiency" (draft notes), August 30, 1994; Asilomar, California. Golden, CO: National Renewable Energy Laboratory.

Farhar, B.; Vories, R.; Eckert, J.; Ferguson, T.; Anson, S. (February 17, 1991). "A National Utility Workshop on Very High Efficiency Refrigerator Programs (Golden Carrot)" (Draft Notes), January 24-25, 1991, San Francisco, California. Washington, D.C.: Solar Energy Research Institute.

. (April 14, 1994). Impacts of Incentives on Energy Use in Buildings (Preliminary Draft). Golden, CO: National Renewable Energy Laboratory.

Feldman, S. (1994). "Market Transformation: Hot Topic or Hot Air?" ACEEE 1994 Summer Study on Energy Efficiency in Buildings Proceedings, Panel, Measurement and Evaluation. Washington, D.C. Berkeley, CA: American Council for an Energy Efficient Economy, pp. 8.37-8.47.

Feist, J.; Farhang, R.; Erikson, J.; Stergakes, E.; Brodie, P.; Liepe, P. (1994). "Super Efficiency Refrigerators: The Golden Carrot ${ }^{\circledR}$ from Concept to Reality." ACEEE 1994 Summer Study on Energy Efficiency in Buildings Proceedings, Panel. Washington, D.C. Berkeley, CA: American Council for an Energy Efficient Economy, pp. 3.67-3.73.

Fernstrom, G. (1991). "Welcoming Remarks." Abstracts from A National Utility Workshop of Very High Efficiency Refrigerator Programs, January 24-25, 1991, San Francisco, California. Fairfax, VA: ICF Resources, Inc., p. 1.

Frigidaire Company. (June 29, 1993). "SERPTM Program Was Great Step to Advance Energy-Efficient, Environmentally Friendly Appliances" (news release). Dublin, OH: Frigidaire Company.

. (June 29, 1993). Note to Correspondents. Washington, D.C.: U.S. Environmental Protection Agency.

Geller, H. (1986). "Analysis of Minimum Efficiency Standards and Rebate Incentive Programs for Domestic Refrigerators in the Pacific Northwest." ACEEE 1986 Summer Study on Energy Efficiency in Buildings Proceedings, Panel on Mandatory Measures. Washington, D.C. Berkeley, CA: American Council for an Energy Efficient Economy, pp. 6.26-6.38.

Global Environmental Change Report. (December 9, 1994). "New US 'Golden Carrot' Efficiency Initiatives Launched." Global Environmental Change Report, Vol. VI, No. 23, pp. 7-8. 
(February 10, 1995). "Vacuum Panels Reach US Market." Global Environmental Change

Report, Vol. VI, No. 3, p. 7.

Golden Carrot Executive Committee. (July 1991a). Golden Carrot Executive Committee Meeting Minutes, June 14, 1991, Washington, D.C. Fairfax, VA: ICF Resources.

(May 1991b). Golden Carrot Executive Committee Meeting Minutes, April 24, 1991, Phoenix, Arizona. Fairfax, VA: ICF Resources.

Washington, D.C.

(1991c). Golden Carrot Executive Committee Meeting Minutes, March 11, 1991,

(1991d). "The Golden Carrot Super-Efficient Refrigerator Program: Replacement and

Early Retirement of Refrigerators in the Mid-1990s" (Redraft of May 13, 1991).

- (1991e). "The Golden Carrot Super Efficient Refrigerator Program: Replacement and Early Retirement of Refrigerators in the Mid-1990s" (Redraft of February 8, 1991).

Goldstein, D. (1994). "Market Transformation to Super Efficient Products: The Emergence of Partnership Approaches." ACEEE 1994 Summer Study on Energy Efficiency in Buildings Proceedings, Panel 6, Policy. Washington, D.C., Berkeley, CA: American Council for an Energy Efficient Economy, pp. 6.91-6.99.

HFD—Retailing Home Furnishings. (May 31, 1993). "U-Line Ends Insulating CFC Use." p. 140.

. (July 5, 1993). "Whirlpool Wins SERPTM Contest: Super-efficient side-by-side refrigerators will ship in first quarter of 1994." pp. 70, 73, 75.

. (January 17, 1994). "'94 Product Preview." p. 214.

. (January 31, 1994). "Builders' Show Optimism a Given." p. 96.

Hoffman, J. (n.d.) Super-Efficient Refrigerators: The Potential of Advanced Technology to Provide Low Cost Demand Reductions and Profitable Pollution Prevention Through a Program of Early Retirement. Washington, D.C.: U.S. Environmental Protection Agency.

Holusha, J. (June 30, 1993). "Whirlpool Takes Top Prize in Redesigning Refrigerator." New York Times.

ICF Resources, Inc. 1991. Abstracts from A National Utility Workshop on Very High Efficiency Refrigerator Programs, January 24-25, 1991, Washington, D.C. Fairfax, VA: ICF Resources, Inc.

Incantalupo, T. (July 1, 1993). "Super Refrigerator, Funded by Utilities, Ready to Hit Stores." Newsday.

Investor's Business Daily. (June 30, 1993). "Whirlpool Wins Bragging Rights for Energy-Efficient Refrigerator."

Joshi, P. and Parrish, M. (June 30, 1993). "A Cool $\$ 30$ Million: Whirlpool Wins Prize for Designing Environmentally Safe Refrigerator." Los Angeles Times, Washington Edition/Design, p. B6.

Kiernan, V. (July 18, 1994). "A Greener White House." Technology Review, pp. 17-18. 
Langreth, R. (January 1994). "The $\$ 30$ Million Refrigerator: How Whirlpool Designed America’s Most Energy-Efficient Icebox." Popular Science, p. 65.

L'Ecuyer, M. (1992). "The Golden Carrot Super-Efficient Refrigerator Program: Encouraging Advanced, Non-CFC Refrigerator Technology in the 1990's." American Association for the Advancement of Science Conference, Chicago, February 10, 1992. Washington, D.C.: U.S. Environmental Protection Agency.

L'Ecuyer, M.; Sachs, H.M.; Fernstrom, G.; Goldstein, D.; Klumpe, E.; Nadel, S. (1992). "Stalking the Golden Carrot: A Utility Consortium to Accelerate the Introduction of Super-Efficient, CFC-Free Refrigerators." ACEEE 1992 Summer Study on Energy Efficiency in Buildings Proceedings, Panei 5, Utility Programs. Washington, D.C. Berkeley, CA: American Council for an Energy Efficient Economy, pp. 5.137-5.145.

Lee, A.; Onisko, S.A.; Sandahl, L.J.; Butter, J. (March 1994). "Everyone Wins-A Program to Upgrade Energy Efficiency in Manufactured Housing." Electricity Journal, pp. 77-86.

Lippman, T. (December 20, 1992). "A New Cold War Aims to Produce A Finer Fridge: Utilities Offer $\$ 30$ Million Prize for Energy, Environmental Gains." Washington Post; Business section, p. H1.

McCabe, M. (1991). Presentation at a National Utility Workshop on Very High Efficiency Refrigerator Programs, January 24-25, 1991, San Francisco, California (Draft Notes by Barbara Farhar). Washington, D.C.: Solar Energy Research Institute, p. 3.

McCoy, C. (December 8, 1992). "Two Big Firms to Vie to Build a Better Fridge." Wall Street Journal, Marketplace/Technology section, p. B1.

Nadel, S.; Geller, H. (1994). "Market Transformation Programs: Past Results, Future Directions." ACEEE 1994 Summer Study on Energy Efficiency in Buildings, Panel 10, Program Design. Washington, D.C., Berkeley, CA: American Council for an Energy Efficient Economy, pp. 10.187-10.197.

Office of Atmospheric and Indoor Air Programs. (February 1992). Multiple Pathways to Super Efficient Refrigerators. Washington, D.C.: U.S. Environmental Protection Agency.

(June 1993). Multiple Pathways to Super-Efficient Refrigerators. EPA-430-R-93-008. Washington, D.C.: U.S. Environmental Protection Agency.

Office of Technology Assessment. (May 1992). Building Energy Efficiency. OTA-E-518. Washington, D.C.: U.S. Government Printing Office.

Pennsylvania Industry Environmental Advisor. (December 1992). "Green Power?" Pennsylvania Industry Environmental Advisor.

Perry, T. (August 1994). "‘Green’ Refrigerators." IEEE Spectrum. 31:8. August.

$P R$ Newswire. (April 18, 1994). "Refrigerator That Won $\$ 30$ Reaches Market." $P R$ Newswire. 18.

Sabin, R. (July 12, 1993). "SERPTM's \$30M Prize Goes to Whirlpool: Super refrigerator will ship 1st qr. '94." Twice, This Week in Consumer Electronics, p. 10. 
Sanders, C. (June 22, 1993). Marketplace; National Public Radio, 6:00-6:30 p.m.

Schiller, Z. (July 5, 1993). "Frigidaire's Run for the Cold Cash." Business Week, p. 81.

Super Efficient Refrigerator Program, Inc. (November 1993). SERP ${ }^{T M}$ promotional brochure.

The Energy Report. (February 6, 1995). "DOE Gives $\$ 800,000$ to Consortium to Promote Energy Tech." The Energy Report, February 6, p. 96.

Treece, J. (July 15, 1993). "The Great Refrigerator Race: How a Whirlpool design team chased $\$ 30$ million in prize money." Business Week, pp. 78-81.

Turiel, I.; Berman, D.; Chan, P.; Chan, T.; Koomey, J.; Lebot, B.; Levine, M.; McMahon, J.; Rosenquist, G.; Stoft, S. (1990). "U.S. Residential Appliance Energy Efficiency: Present Status and Future Directions." ACEEE 1990 Summer Study on Energy Efficiency in Buildings Proceedings, Panel 1, Building Equipment and Appliances. Washington, D.C. Berkeley, CA: American Council for an Energy Efficient Economy, pp. 1.213-1.234.

U.S. Environmental Protection Agency. (1993/1994). "Golden Carrot Super Efficient Refrigerator Program" (Fact Sheet). Energy, R-144. Washington, D.C.: U.S. Environmental Protection Agency Library.

Vine, E.L., et al. (1994). "Evaluation of Commercial Lighting Programs: A DEEP Assessment." ACEEE 1994 Summer Study on Energy Efficiency in Buildings Proceedings, Panel 8, Measurement and Evaluation, Washington, D.C., Berkeley, CA: American Council for an Energy Efficient Economy, pp. 8.237-8.245.

Whirlpool Corporation. (June 29, 1993). "Whirlpool Corporation Named Winner in $\$ 30$ Million SuperEfficient Refrigerator Competition" (News Release). Benton Harbor, MI: Whirlpool Corporation.

White, R.; Wheat, T. (July 7, 1993). "LTV, Inland in Line for 'Super Frig.'" American Metal Market, p. 3.

(December 15, 1994). Written communication to Barbara Farhar, p. 1.

Wrigley, A. (July 12, 1993). "“Clean’ Refrigerators to Hum." American Metal Market, p. 6. 


\section{Appendix A}

NAECA standards are specific to each refrigerator based on size and features. The following table lists the equations used to identify $R / F$ standards for selected product classes. Adjusted Volume (AV) is calculated as (freezer volume $\times 1.63$ ) + fresh food volume. To determine $\mathrm{kWh} / \mathrm{yr}$ for a product class, determine the AV for the class, then add to the second number in the equation.

\section{Comparison of 1990 and 1993 Federal Energy Standards Equations for R/Fs*}

\begin{tabular}{|c|c|c|}
\hline Product Class & 1990 NAECA Standards & 1993 Energy Standards \\
\hline $\mathrm{R} / \mathrm{Fs}$ - manual defrost & $16.3 \mathrm{AV}+316$ & $19.9 \mathrm{AV}+96$ \\
\hline $\mathrm{R} / \mathrm{Fs}$ - partial automatic defrost & $21.8 \mathrm{AV}+429$ & $10.4 \mathrm{AV}+396$ \\
\hline $\begin{array}{l}\mathrm{R} / \mathrm{Fs} \text { - automatic defrost with top- } \\
\text { mounted freezer }\end{array}$ & $23.5 \mathrm{AV}+471$ & $16.0 \mathrm{AV}+355$ \\
\hline $\begin{array}{l}\mathrm{R} / \mathrm{Fs} \text { - automatic defrost with side- } \\
\text { mounted freezer }\end{array}$ & $27.7 \mathrm{AV}+488$ & $11.8 \mathrm{AV}+501$ \\
\hline $\begin{array}{l}\text { R/Fs - automatic defrost with bottom- } \\
\text { mounted freezer }\end{array}$ & $27.7 \mathrm{AV}+488$ & $14.2 \mathrm{AV}+364$ \\
\hline $\begin{array}{l}\mathrm{R} / \mathrm{Fs} \text { - automatic defrost with top- } \\
\text { mounted freezer with through-the-door } \\
\text { ice service }\end{array}$ & $26.4 \mathrm{AV}+.535$ & $17.6 \mathrm{AV}+391$ \\
\hline $\begin{array}{l}\mathrm{R} / \mathrm{Fs} \text { - automatic defrost with side- } \\
\text { mounted freezer with through-the-door } \\
\text { ice service }\end{array}$ & 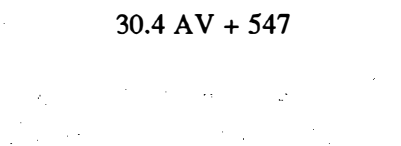 & $16.3 \mathrm{AV}+527$ \\
\hline
\end{tabular}

*1990 and 1993 standards for an R/F with the same dimensions and features as a SERP model (freezer volume of $7.1 \mathrm{ft}^{3}$ and fresh food volume of $14.5 \mathrm{ft}^{3}$ ) would have been $1329 \mathrm{kWh} / \mathrm{yr}$ and $951 \mathrm{kWh} / \mathrm{yr}$, respectively (calculated using data from Whirlpool Corporation).

Source: DOE Office of Conservation and Renewable Energy (1989), p. 47, 919. 


\section{Appendix B}

This Appendix lays out the assumptions underlying the figures in Table 3. For the purposes of these calculations, the author assumed that:

- Whirlpool will manufacture and sell a total of 250,000 refrigerators with a per-unit consumption of $670 \mathrm{kWh}$; comparable models complying with NAECA standards consume $953 \mathrm{kWh}$ /year (Source: SERPTM, Inc.)

- The average life per R/F is 14 years (Source: Appliance Magazine. (1993). Cited in DOE/OBT Core. Databook, June 24, 1994, Table 5.6.19, pp. 5-22)

- Approximately $0.07 \%$ of energy produced is lost during transmission and distribution (T\&D) (Source: EIA Annual Outlook. (1994). Cited in DOE/OBT Core Databook, June 24, 1994, p. 1)

- Energy savings per SERPTM unit is $283 \mathrm{kWh} /$ year at point of end use and $302.8 \mathrm{kWh} /$ year at point of generation

- Emissions in $\mathrm{lb} / \mathrm{kWh}$ are 1.329 for $\mathrm{CO}_{2}, 0.00564$ for $\mathrm{NO}_{\mathrm{x}}$, and 0.010 for $\mathrm{SO}_{2}$ (Source: Calculated from Electric Power Annual 1992. (January 1994). DOE/EIA-0348(92), Table 12 on net generation, Table 46 emissions)

- The 1993 national average cost per kWh is $\$ 0.083$ (Source: Monthly Energy Review. (April 1994). DOE/EIA-0035 [94/04]).

\section{Total Energy Savings:}

$302.8 \mathrm{kWh}$ saved/year $\times 250,000=\frac{75,700,000 \mathrm{kWh} / \text { year }}{1,000 \mathrm{kWh}}=75,700 \mathrm{MWh} /$ year $=1,059,800 \mathrm{MWh}$

$$
1,000 \mathrm{kWh}
$$
over 14 years

\section{Total Consumer Savings:}

$283 \mathrm{kWh} /$ year $\times \$ 0.083=\$ 23.50 /$ year/unit saved

$\$ 23.50 \times 250,000=\$ 5,875,000=\$ 82,250,000$ over 14 years

\section{Decrease in $\mathrm{CO}_{2}$ Emissions:}

[283 kWh/year $\times 1.07($ energy lost during $\mathrm{T} \& \mathrm{D})=302.8 \mathrm{kWh} /$ year $] \times 1.329 \mathrm{lb} \mathrm{CO} / \mathrm{kWh} /$ year $=$ $402.43 \mathrm{lb} \mathrm{CO}_{2} / \mathrm{kWh}$ year saved per SERPTM unit

$402.43 \mathrm{lb} \mathrm{CO}_{2} / \mathrm{kWh} /$ year per unit $\times 250,000 \mathrm{SERP}{ }^{\mathrm{TM}}$ units $=\frac{100,608,620 \mathrm{lb} / \mathrm{kWh} / \text { year }}{2,000 \mathrm{lb}}=$ 50,304 tons $\times 1.102=55,435 \mathrm{MT}$ of $\mathrm{CO}_{2}$ per year $=0.78 \mathrm{MMT}$ over 14 years 


\section{Decrease in $\mathrm{NO}_{\mathbf{x}}$ Emissions:}

[283 kWh/year $\times 1.07($ energy lost during $\mathrm{T} \& \mathrm{D})=302.8 \mathrm{kWh} /$ year] $\times 0.00564 \mathrm{lb} \mathrm{NO} / \mathrm{kWh} / \mathrm{year}=$ $1.707 \mathrm{lb} \mathrm{NO} / \mathrm{kWh} /$ year saved per SERP ${ }^{\mathrm{TM}}$ unit

$1.707 \mathrm{lb} \mathrm{NO} / \mathrm{xWh} /$ year per unit $\times 250,000 \mathrm{SERP} \mathrm{PM}^{\mathrm{TM}}$ units $=\frac{426,948 \mathrm{lb} / \mathrm{kWh} / \text { year }}{2,000 \mathrm{lb}}=$ 213 tons $\times 1.102=235.2 \mathrm{MT}$ of $\mathrm{NO}_{\mathrm{x}}$ per year $=3,293 \mathrm{MT}$ over 14 years

\section{Decrease in $\mathrm{SO}_{2}$ Emissions:}

[283 kWh/year $\times 1.07$ (energy lost during $\mathrm{T} \& \mathrm{D})=302.8 \mathrm{kWh} /$ year $] \times 0.010 \mathrm{lb} \mathrm{SO} / \mathrm{kWh} / \mathrm{year}=$ $3.02 \mathrm{lb} \mathrm{SO}_{2} / \mathrm{kWh}$ year saved per SERP ${ }^{\mathrm{TM}}$ unit

$3.02 \mathrm{lb} \mathrm{SO}_{2} / \mathrm{kWh}_{\text {year per unit } \times 250,000 \mathrm{SERP}}{ }^{\mathrm{TM}}$ units $=\frac{757,000 \mathrm{lb} / \mathrm{kWh} / \text { year }}{2,000 \mathrm{lb}}=$ 378.5 tons $\times 1.102=417 \mathrm{MT}$ of $\mathrm{SO}_{2}$ per year $=5,838 \mathrm{MT}$ over 14 years 


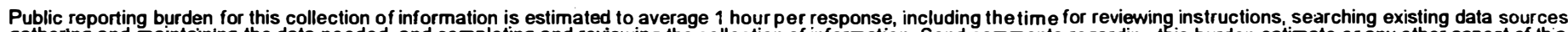

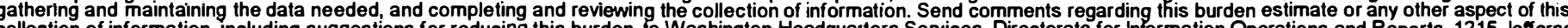

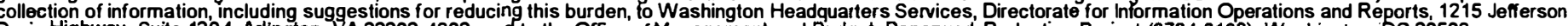
Davis Highway, Suite 1204, Arlington, VA 22202-4302, and to the Office of Management and Budget, Paperwork Reduction Project (0704-0188), Washington, DC 20503.
1. AGENCY USE ONLY (Leave blank)
2. REPORT
3. REPORT TYPE AND DATES COVERED
DATE
technical report
July 1995

4. TITLE AND SUBTITLE

The Super Efficient Refrigerator Program: Case Study of a Golden Carrot Program

5. FUNDING NUMBERS

AS135441

6. AUTHOR(S)

J. Ėckert

7. PERFORMING ORGANIZATION NAME(S) AND ADDRESS(ES)

National Renewable Energy Laboratory

1617 Cole Boulevard

Golden, Colorado 80401-3393

8. PERFORMING ORGANIZATION REPORT NUMBER

TP-461-7281

9. SPONSORING/MONITORING AGENCY NAME(S) AND ADDRESS(ES)

U.S. Department of Energy

1000 Independence Ave., SW

Washington, DC 20585

11. SUPPLEMENTARY NOTES

12a. DISTRIBUTION/AVAILABILITY STATEMENT National Technical Information Service

U.S. Department of Commerce

5285 Port Royal Road

Springfield, VA 22161 12b. DISTRIBUTION CODE

UC 1600

13. ABSTRACT (Maximum 200 words)

This case study describes the development and implementation of the Super Efficient Refrigerator Program (SERP), which awarded \$30 million to the refrigerator manufacturer that developed and commercialized a refrigerator that exceeded 1993 federal efficiency standards by at least $25 \%$. Twenty-four public and private utilities funded the program. As the first Golden Carrot program implemented in the United States, SERP was studied as an example for future "market-pull" efforts.

14. SUBJECT TERMS

super-efficient refrigerator; golden carrot; market pull; efficient appliances

15. NUMBER OF PAGES

54

16. PRICE CODE

17. SECURITY CLASSIFICATION OF REPORT

unclassified
18. SECURITY CLASSIFICATION OF THIS PAGE unclassified
19. SECURITY CLASSIFICATION OF ABSTRACT unclassified
20. LIMITATION OF ABSTRACT

UL 